\title{
Genetic Diversity and Population Assessment of Musa L. (Musaceae) Employing CDDP Markers
}

\author{
David Okeh Igwe ${ }^{1,2}$. Onyinye Constance Ihearahu ${ }^{1}$. Anne Adhiambo Osano ${ }^{1}$. George Acquaah ${ }^{1}$. \\ George Nkem Ude ${ }^{1} \mathbb{D}$
}

Received: 3 October 2020 / Accepted: 22 March 2021 / Published online: 21 April 2021

(c) The Author(s) 2021

\begin{abstract}
Sixty-six accessions of Musa genus with different genomic groups that consisted of wild relatives and cultivated lines were obtained from the International Transit Center, Belgium, for DNA extraction using Cetyl trimethylammonium bromide method, followed by amplification with Conserved DNA-derived Polymorphism (CDDP) markers for genetic diversity and population assessment. A total of 421 alleles with major allele frequency of 2.051 were detected from the reproducible markers. High genetic diversity (GD, 11.093) and polymorphic information content (0.918) were revealed. The number of polymorphic loci and percentage of polymorphic loci ranged from 59 to 66 and 89.34 to 100, respectively. Using the potential genetic indicators including effective number of alleles, Nei's genetic diversity, and Shannon's information index, the AS genomic group was identified to have the highest GD, while the AAA accessions had the lowest GD indices. The GD parameters identified in the accessions were ranked as $\mathrm{AS}>\mathrm{AAB}>\mathrm{AAAA}>\mathrm{AA}>\mathrm{ABB}>$ wild diploidy $>\mathrm{BB}>\mathrm{AB}>\mathrm{AAA}$ from high to low based on polymorphic loci of the markers. Total intraspecific GD, interspecific GD, and estimate gene flow identified were $0.433,0.404$, and 7.113 , respectively. The coefficient of gene differentiation of 0.066 was obtained, indicating $6.57 \%$ among the population and $93.43 \%$ within the population. Dendrogram analysis produced nine major groups with subgroups at similarity index of 0.814 . These CDDP functional gene-based markers were informative and very efficient in resolving GD, and population indices among the banana and plantain accessions of different genomes. The identified CDDP markers might serve as potential tools for selecting suitable training populations for breeding and conservation of Musa species.
\end{abstract}

Keywords Alleles $\cdot$ Number of polymorphic loci $\cdot$ Shannon's information index $\cdot$ Interspecific genetic diversity Accessions · Nei's gene diversity

\section{Introduction}

Key Message

- Genetic diversity and population indices of bananas and plantains with variable genomic groups (AA, AAA, AAAA, $\mathrm{AAB}, \mathrm{BB}, \mathrm{AB}, \mathrm{ABB}, \mathrm{AAAB}, \mathrm{AS}$, and wild diploid accessions) were revealed by Conserved DNA-derived Polymorphism (CDDP) markers. The selected CDDP markers may serve as potential tools in choosing suitable training populations of Musa species.

\section{George Nkem Ude}

gude@bowiestate.edu

1 Department of Natural Sciences, Bowie State University, 14000 Jericho Park Road, Bowie, MD 20715, USA

2 Department of Biotechnology, Ebonyi State University, Abakaliki, Ebonyi State, Nigeria
Bananas and plantains, Musa L. (Musaceae Juss.), are perennial crops with rapid growth rate and are cultivated all the year round within tropics and sub-tropics. They are the favorite fruit crops of the world and are globally distributed in more than 120 countries, with a total production of approximately 106 million tonnes per year (Molina and Kudagamage 2002). In 2012, the global production was estimated at about 140 million metric tons (FAOStat 2014). They are regarded as the highest export fruit crops (FAO 2011) and rated fourth most important in sub-Saharan Africa (SSA) after cassava, maize, and yam (FAO 2009). Bananas and plantains are rich sources of carbohydrates, vitamin C, potassium, and sodium (IBA 2007). The different genotypes were derived from Musa acuminata (AA) and M. balbisiana 
(BB) and classified into different genomic groups including diploids ( $\mathrm{AA}, \mathrm{AB}$, and $\mathrm{BB}$ ), triploids (AAA, $\mathrm{AAB}, \mathrm{ABB}$, and $\mathrm{BBB}$ ), and tetraploids (AAAA, $\mathrm{AAAB}, \mathrm{AABB}$, and ABBB) (Pollefeys et al.2004; INIBAP 2003). Also, East African (mainly dessert) bananas (AA, AAB, AAA, ABB, and $\mathrm{AB}$ ) and the African plantains (AAB) are grown mainly in central and west Africa, while the East African Highland Banana (AAA) are for cooking and beer brewing (Karamura et al. 1998).

Production of these vital crops is plagued by pathogenic factors and diverse environmental stresses. With rising global temperatures, which are expected to have drastic effects including altered patterns of drought, salinity, and emergence of new pests and diseases, plant growth and yield will be adversely impacted (Tester and Langridge 2010). For example, drought has emerged as one of the major constraints in banana production in the tropics and sub-tropics. Bananas are quite sensitive to drought; interestingly, genotypes with "B" genome (in particular ABB type) are more tolerant to abiotic stresses than those solely possessing " $\mathrm{A}$ " genome. However, the combination of varied topography and arid/semi-arid climatic conditions calls for drought resistant genotypes to these factors to be developed. This is vital since the world population is fast growing and is expected to reach over 9 billion by the year 2050 (FAO 2015). Feeding this overwhelming population level is generating much pressure on agricultural crop production (Kastner et al. 2012; Dempewolf et al. 2014; Khoury et al. 2014). To increase food supply, especially Musa species, harnessing genetic diversity and novel traits could result in developing new genotypes that are capable of withstanding changing environmental factors, since populations with narrower range may fail to survive climatic extremes.

Breeders need plants that are resistant to abiotic and biotic stressors, but this goal cannot easily be achieved via conventional breeding due to the complicated genetic system of Musa species. However, it is possible with molecular markers that are not influenced by changes in environmental factors with time and can target different genes (Martínez et al. 2006). Different molecular marker techniques such as random amplified polymorphic DNA (RAPD) marker (Kaemmer 1992; Ude et al. 2003; Toral et al. 2009; Lamare and Rao 2015), restriction fragment length polymorphism (RFLP) (Gawel et al. 1992; Bhat et al. 1995; Ning et al. 2007), simple sequence repeat (SSR) (Buhariwalla et al. 2005; Christelova et al. 2011; Hippolyte et al. 2012; de Jesus et al. 2013; Nyine et al. 2017), genotyping by sequencing (GBS) (Elshire et al. 2011), inter-simple sequence repeats (ISSR) (Godwin et al. 1997; Silva et al. 2016), directed amplified minisatellite DNA (DAMD) (Lamare and Rao 2015), and amplified fragment length polymorphism (AFLP) (Bhat et al. 1995; Ude et al. 2002a, b; Wang et al. 2007; Opara et al. 2010) have been utilized in dissecting genetic diversity, population, and genetic constitutions of Musa species. Other advanced tools including proteomics (Toledo et al. 2012; Bhuiyan et al. 2020), clustered regularly interspaced short palindromic repeats (CRISPR)/ CRISPRassociated protein 9 (Cas9) (Tripathi et al. 2019; Ntui et al. 2020), and gene expression (Yang et al. 2015; Sanchez et al. 2016; Wang et al. 2017) have been utilized in bananas and plantains to address several challenging factors that are militating against improved breeding and productivity. However, there are more informative and cost-effective molecular markers that target conserved domains and can effectively exploit the genetic indices or genepools inherent in banana and plantain plants as well as their wild relatives for crop genetic improvement. It has been reported that structural variant genes possessing presence or absence of variants contribute to diversity genepool (Golicz et al. 2016). Identification of Musa accessions (wild and elite ones) that can be adopted and optimized to perform in diverse environmental conditions based on abundant allelic diversity is very important since the optimal development of these accessions is dependent on the allelic/genetic diversity (Montenegro et al. 2017). To reveal the degree of genetic diversity and population structure inherent in these accessions, informative molecular markers including conserved DNA-derived polymorphism (CDDP) genes are required to characterize the allelic pool diversity and population. Conserved DNAderived polymorphism markers involving transcriptional factors (TFs: MYB, ERF, WRKY, and APB) are cost-effective marker techniques that target conserved sequences of plant functional genes (mainly involved in responses to abiotic and biotic stressors or plant development) and possibly produce candidate markers that may be partly or completely associated with known genes (Collard and Mackill 2009). Furthermore, CDDP marker techniques are agarose gel-based, convenient, highly polymorphic, and capable of generating markers that are phenotypically linked to traits (Collard and Mackill 2009). The CDDP markers are similar in principle to resistance gene analog markers, designed from conserved regions in plant disease resistance genes (Chen et al. 1998). They possess different putative domains including auxinbinding proteins, transcriptional factors for development, physiology, fruiting and ripening processes, plant disease resistance pathway, secondary metabolism, abiotic and biotic stresses, and cellular morphogenesis (D'Hont et al. 2012). It has been shown that within functional domains of well characterized plant genes, the CDDPs can generate informative banding patterns that are utilized for mapping, trait association, and germplasm genetic diversity studies (Collard and Mackill 2009; Poczai et al. 2013). Due to the inherent efficiency and ability of CDDP to easily generate functional markers (FMs) that are associated with given plant phenotypic expressions, they have been used in the improvement of different crops including Rosa rugosa Thunb. ex Murray 
(Jin et al. 2016; Jiang and Zang 2018), Chrysanthemum L. cultivars (Li et al. 2013), Peony (Paeonia L.) cultivar (Li et al. 2014), bittersweet (Solanum dulcamara L.) (Poczai et al. 2011), date palm (Phoenix dactylifera L.)(Mam et al. 2017), Chickpea (Cicer arietinum L.) (Hajibarat et al. 2015), rice (Oryza sativa L.) (Collard and Mackill 2009), and wheat (Triticum aestivum L.) (Hamidi et al. 2014; Seyedimoradi et al. 2016). However, in bananas and plantains, utility of CDDP markers has not yet been reported to our knowledge for genetic diversity and population assessment. Therefore, the objective of this study was to access the genetic diversity/allelic richness and population of variable genomic constitutions of cultivated and wild relatives of Musa species using CDDP markers.

\section{Materials and Methods}

\section{Sample Collection, DNA Extraction, Quantification and Preparation of Working Dilutions}

Sixty-six accessions of bananas and plantains from different genomic groups consisting of AA, AAA, AAAA, AAB, BB, $\mathrm{AB}, \mathrm{ABB}, \mathrm{AAAB}$, and $\mathrm{AS}$, as well as other three wild diploid accessions (Musa beccarii, M. coccinea, and M. textilis) were obtained from the Musa germplasm collection of Diversity's International Transit Center (ITC), hosted by Leuven, Belgium (Ruas et al. 2017) (Table 1). These accessions were mostly derived from the hybridization between wild diploid subspecies of M. acuminata and M. balbisiana. Thirty-two out of 66 were obtained as tissue cultured plantlet materials, each in five replicates and were grown and maintained at the screenhouse of the Department of Natural Sciences, Bowie State University, while the remaining 34 were obtained in lyophilized condition from the same ITC. Approximately $100 \mathrm{mg}$ and $120 \mathrm{mg}$ were respectively weighed from young fresh and lyophilized leaves of Musa species for DNA extraction using Cetyl trimethylammonium bromide (CTAB) method (Abarshi et al. 2010) with little modifications, using a ratio of 24:1 of chloroform and isoamyl alcohol, respectively, without phenol.

\section{Polymerase Chain Reaction and Agarose Gel Electrophoresis}

Polymerase chain reaction (PCR) amplification was performed in volume of $25 \mu \mathrm{L}$ which consisted of $2.0 \mu \mathrm{L} 100 \mathrm{ng}$ DNA, $5.0 \mu \mathrm{l}$ of $5 \times$ Green GoTaq Buffer (Promega Corporation, Madison, USA), $2.0 \mu \mathrm{l}$ of $2.5 \mathrm{mM}$ dNTPs (Bioline, Massachusetts, USA), and $0.2 \mu \mathrm{l}$ GoTaq DNA polymerase ( $5 \mathrm{U} / \mu \mathrm{l})$ (Promega Corporation, Madison, USA), $1.0 \mu \mathrm{l}$ of $10 \mu \mathrm{M}$ each of CDDP primer, and $14.80 \mu \mathrm{l}$ of $500 \mathrm{ml}$ diethyl pyrocarbonate (DEPC)-treated water (Invitrogen, Carlsbad, CA, USA). The names of CDDP primers, their functions, sequences, GC
Table 1 List of accessions of different groups of bananas and plantains used for this study

\begin{tabular}{|c|c|c|}
\hline ITC code & Accession name & Genomic group \\
\hline ITC0101 & "Fougamou 1" & $\mathrm{ABB}$ \\
\hline ITC0109 & "Obino I'Ewai" & $\mathrm{AAB}$ \\
\hline ITC0249 & "Calcutta 4" & AA \\
\hline ITC0336 & "Improved Lady Finger" & $\mathrm{AAB}$ \\
\hline ITC0338 & "Blue Torres Strait Island" & $\mathrm{ABB}$ \\
\hline ITC0348 & "Silk" & $\mathrm{AAB}$ \\
\hline ITC0393 & "Truncata" & AA \\
\hline ITC0394 & "Cardaba" & $\mathrm{ABB}$ \\
\hline ITC0395 & "Lidi" & AA \\
\hline ITC0396 & "Pelipita" & $\mathrm{ABB}$ \\
\hline ITC0397 & "Pelipita Manjoncho" & $\mathrm{ABB}$ \\
\hline ITC0403 & "Lai”" & AAA \\
\hline ITC0428 & "Higa" & AA \\
\hline ITC0448 & "Pisang Keling" & $\mathrm{AAB}$ \\
\hline ITC0449 & "Pisang Lawadin" & $\mathrm{AAB}$ \\
\hline ITC0473 & "Balonkawe" & $\mathrm{ABB}$ \\
\hline ITC0484 & "Gros Michel" & AAA \\
\hline ITC0485 & "Green Red" & AAA \\
\hline ITC0498 & "Plantain no. 3" & $\mathrm{AAB}$ \\
\hline ITC0500 & "Pata" & $\mathrm{ABB}$ \\
\hline ITC0547 & "Chinese Cavendish" & AAA \\
\hline ITC0548 & "Dwarf Parfitt" & AAA \\
\hline ITC0549 & "Hochuchu" & AAA \\
\hline ITC0550 & “Umalag” & AAA \\
\hline ITC0551 & "Hsein Jen Chiao" & AAA \\
\hline ITC0552 & "Mons Mari” (Pedwell) & AAA \\
\hline ITC0582 & "Lady Finger" (Nelson) & $\mathrm{AAB}$ \\
\hline ITC0587 & $\begin{array}{l}\text { "Pisang Rajah" (South } \\
\text { Johnstone) }\end{array}$ & $\mathrm{AAB}$ \\
\hline ITC1120 & “Tani” & $\mathrm{BB}$ \\
\hline ITC1121 & "Pisang Lilin" & AA \\
\hline ITC1137 & "Poteau Geant" & $\mathrm{ABB}$ \\
\hline ITC1587 & "Pisang Klutuk Wulung" & $\mathrm{BB}$ \\
\hline ITC0017 & "Garbon 2" & $\mathrm{AAB}$ \\
\hline ITC0966 & “Zebrina” (G.F) & AA \\
\hline ITC0660 & "Khae" (Phrae) & AA \\
\hline ITC Code & Accession name & Genomic group \\
\hline ITC0767 & "Dole" & $\mathrm{ABB}$ \\
\hline ITC1152 & "Wompa" & AS \\
\hline ITC0450 & "Pisang Palembang" & $\mathrm{AAB}$ \\
\hline ITC0213 & "Pisang Awak" & $\mathrm{ABB}$ \\
\hline ITC0570 & $\begin{array}{l}\text { "Williams" (Bell, South } \\
\text { Johnstone) }\end{array}$ & AAA \\
\hline ITC0352 & Plantain no. 17 & $\mathrm{AAB}$ \\
\hline ITC0652 & "Kluai Tiparot" & $\mathrm{ABB}$ \\
\hline ITC0090 & "Tiau Lagada" & AA \\
\hline ITC0269 & "Niyarma Yik" & AA \\
\hline ITC1060 & "Selangor" & AAAA \\
\hline ITC0093 & "Long Tavoy" & AA \\
\hline
\end{tabular}


Table 1 (continued)

\begin{tabular}{lll}
\hline ITC code & Accession name & Genomic group \\
\hline ITC0250 & "Malaccenesis" & AA \\
ITC0769 & "Figure Pomme Geante" & AAB \\
ITC0263 & "Highgate" & AAA \\
ITC0253 & "Borneo" & AA \\
ITC0247 & "Honduras" & BB \\
ITC0076 & "Pome" & AAB \\
ITC1638 & "Kunnan" & AB \\
ITC1070 & Musa beccarii & beccarii [Ploidy = 2x (1)] \\
ITC0287 & Musa coccinea & coccinea [Ploidy = 2x (1)] \\
ITC1336 & "JD Yangambi" & AAA \\
ITC1072 & Musa textilis & textilis [Ploidy = 2x (1)] \\
ITC1187 & "Tomolo" & AA \\
ITC0611 & "Pisang Berlin" & AA \\
ITC1265 & FHIA-23 & AAAA \\
ITC0413 & No.110 & AA \\
ITC0002 & "Dwarf Cavendish" & AAA \\
ITC1284 & SH-3436-6 & AAAA \\
ITC1588 & "Lal Velchi” & BB \\
ITC0254 & "Madang" & AA \\
ITC1332 & FHIA-21 (\#68) & AAAB \\
\hline
\end{tabular}

ITC International Transit Center

content, annealing temperatures, and sources (Anai et al. 1997; Nagasaki et al. 2001; Stracke et al. 2001; Jiang et al. 2004; Gutterson and Reuber 2004; Xie et al. 2005) including the ones designed in this study are presented in Table 2. The PCR cycling profile used for the reaction consisted of an initial step at $94{ }^{\circ} \mathrm{C}$ for $5 \mathrm{~min}$., followed by 40 cycles of $94{ }^{\circ} \mathrm{C}$ for $30 \mathrm{~s}$, $72{ }^{\circ} \mathrm{C}$ for $1 \mathrm{~min}$, and a 10 -min final extension at $72{ }^{\circ} \mathrm{C}$ using a Bio-Rad T100 Thermal cycler (Bio-Rad Laboratories Inc. Singapore). The PCR reaction products of $10 \mu \mathrm{l}$ were electrophoresed in a $1.5 \%$ agarose gel containing $0.5 \mathrm{mg} / \mathrm{ml}$ ethidium bromide and photographed using Aplegen Omega Lum G gel documentation system (Minnesota 55,303, USA). Prior to analysis of all the accessions, we selected few accessions of variable genomes and amplified them with all the CDDP primers for optimizations, and then identified the reproducible ones with scorable bands, after repetition for the amplifications of all the 66 accessions.

\section{Data Analyses}

Data matrices of CDDP marker profiles were generated by scoring (1) for presence and (0) for absence of individual allele. The generated data matrices were used for genetic diversity, allele frequency, and polymorphic information content (PIC) and were computed using PowerMarker version 3.25 (Liu and Muse 2005). Analyses of percentage polymorphic loci (PPL), effective number of alleles (Ne)
(Kimura and Ohta 1973), Nei's gene diversity (NGD) (Nei 1973), Shannon's information index (I) (Lewontin 1972) (very important parameters usually used in assessing genetic diversities despite the number of sample or population sizes), and population (total gene diversity or intraspecific genetic diversity, $\mathrm{Ht}$; gene diversity within population of interspecific genetic diversity, Hs; coefficient of gene differentiation, $G_{\mathrm{ST}}$; and level of gene flow, $\mathrm{Nm}$ ) of the accessions were analyzed using POPGENE software version 1.32 (Yeh and Boyle 1997). Dendrogram reconstruction using Unweighted Pair Group Mean Arithmetic (UPGMA) and dissimilarity index in Jaccard's option (Igwe et al. 2017) was conducted using NTSYSpc software version 2.02 (Rohl 2000). Principal component analysis (PCA) of the accessions was computed using DARwin software version 6.0.021 (Perrier and Jacquemoud-Collet 2006).

\section{Results}

\section{Allelic Variation, Gene Diversity, and Polymorphic Information Content}

Out of the fifteen primers of CDDP markers tested, twelve were found to be reproducible and scorable as indicated in some of the representatives of the gel images generated for analyses (Figs. 1, 2, 3, 4). A total of 421 numbers of alleles were generated from the reproducible ones (Table 3 ). The range of amplifiable alleles from the primers was from 20 to 51 , with a mean of 35.083 . The major allele frequency was 2.051 , and it ranged from 0.046 to 0.454 , with a mean value of 0.171 . Gene diversity with a total value of 11.093 and mean of 0.924 , ranged from 0.782 to 0.757 . Polymorphic information content with a total value of 11.019 , ranged from 0.768 to 0.975 , with a mean of 0.918 . The CDDP primers including ERF1, ERF2, WRKYMusa1a, KNOX1, MYB2, WRKY-R1, KNOX-2, KNOX1M1a, MYB1, and WRKY-F1 demonstrated high polymorphisms, while ABP1-3 and ABP1-1 were monomorphic. The PIC values detected in the CDDP primers were ranked in a descending order as MYB $1>$ ERF1 $>$ WRKY-F1 > WRKY-R1 $>$ KNOX$1>$ KNOX1M1a $>$ MYB2 $>$ ERF2 $>$ KNOX-2 $>$ WRK YMusa1a $>$ ABP1-3 > ABP1-1. Allelic scores, counts, and frequencies obtained from these accessions of Musa species were high. The allelic counts ranged from 1 to 28 , while the frequencies spanned between 0.015 and 0.424 (Supplementary file 1: Table S1).

The identified number of polymorphic loci (NPL) and percentage of polymorphic loci (PPL) obtained from the 12 reproducible set of primers of CDDP markers using 66 accessions ranged from 59 to 66 and 89.34 to 100, respectively (Table 4). Based on the genetic diversity endowment of these primers in Musa species, eight out of the 12 primers 
Table 2 List of primers, their sequences, percentage GC contents, and annealing temperatures

\begin{tabular}{|c|c|c|c|c|c|}
\hline Functions & Primer name & Primer sequence $\left(5^{\prime}-3^{\prime}\right)$ & $\% \mathrm{GC}$ & $\begin{array}{l}\text { Annealing } \\
\text { temperature }\end{array}$ & Source \\
\hline $\begin{array}{l}\text { TF involved in plant disease } \\
\text { resistance pathway }\end{array}$ & ERF1 & CACTACCCCGGSCTSCG & 76.5 & 61.4 & Gutterson and Reuber (2004) \\
\hline Auxin-binding protein & ABP1-3 & CACGAGGACCTSCAGG & 68.8 & 55.1 & Anai et al. (1997) \\
\hline Auxin-binding protein & ABP1-1 & ACSCCSATCCACCGC & 73.3 & 58.7 & Anai et al. (1997) \\
\hline $\begin{array}{l}\text { TF involved in plant disease } \\
\text { resistance pathway }\end{array}$ & ERF2 & GCSGAGATCCGSGACCC & 76.5 & 61.4 & Gutterson and Reuber (2004) \\
\hline $\begin{array}{l}\text { TF developmental and physiologi- } \\
\text { cal roles }\end{array}$ & WRKYMusa1a & AGATGGCTCTTTTGTGGKTT & 67.5 & 53.5 & Igwe et al. (2021) \\
\hline $\begin{array}{l}\text { Homeobox genes for TFs with a } \\
\text { unique homeodomain }\end{array}$ & KNOX-1 & AAGGGSAAGCTSCCSAAG & 68.1 & 58 & Nagasaki et al. (2001) \\
\hline $\begin{array}{l}\text { For metabolism, abiotic and biotic } \\
\text { stresses, cellular morphogenesis }\end{array}$ & MYB2 & GGCAAGGGCTGCCGG & 80.0 & 60.9 & $\begin{array}{l}\text { Jiang et al. (2004) and Stracke } \\
\text { et al.(2001) }\end{array}$ \\
\hline $\begin{array}{l}\text { TF developmental and physiologi- } \\
\text { cal roles }\end{array}$ & WRKY-F1 & TGGCGSAAGTACGGCCAG & 66.7 & 60.8 & Xie et al. (2005) \\
\hline $\begin{array}{l}\text { Homeobox genes for TFs with a } \\
\text { unique homeodomain }\end{array}$ & KNOX-2 & CACTGGTGGGAGCTSCAC & 66.7 & 58.6 & Nagasaki et al. (2001) \\
\hline $\begin{array}{l}\text { Homeobox genes for TFs with a } \\
\text { unique homeodomain }\end{array}$ & KNOX1Mus & ARGGCGAAGCTSCCSAAG & 63.9 & 59.5 & Igwe et al. (2021) \\
\hline $\begin{array}{l}\text { For metabolism, abiotic, and } \\
\text { biotic stresses, cellular morpho- } \\
\text { genesis }\end{array}$ & MYB1 & GGCAAGGGCTGCCGC & 80.0 & 61.5 & $\begin{array}{l}\text { Jiang et al. (2004) and Stracke } \\
\text { et al. (2001) }\end{array}$ \\
\hline $\begin{array}{l}\text { TF developmental and physiologi- } \\
\text { cal roles }\end{array}$ & WRKY-R1 & GTGGTTGTGTCTTGCC & 56.3 & 51.0 & Xie et al. (2005) \\
\hline $\begin{array}{l}\text { TF developmental and physiologi- } \\
\text { cal roles }\end{array}$ & WRKYMus1b & CATGTCCTCCACCAGTASAT & 50.0 & 53.8 & Igwe et al. (2021) \\
\hline $\begin{array}{l}\text { TF developmental and physiologi- } \\
\text { cal roles }\end{array}$ & WRKYMus1c & $\begin{array}{l}\text { GGRGGAGTTAAAGATGGC } \\
\text { TCT }\end{array}$ & 50.0 & 55.2 & Igwe et al. (2021) \\
\hline $\begin{array}{l}\text { TF developmental and physiologi- } \\
\text { cal roles }\end{array}$ & WRKYMus1d & TTCTTCTGCTGGTTCTTCYTC & 45.2 & 53.5 & Igwe et al. (2021) \\
\hline
\end{tabular}

$T F$ Transcriptional factor; \%GC percentage of GC contents

exhibited $100 \%$ polymorphisms, while the lowest obtained from two primers was $89.39 \%$. Within the 12 CDDP primers, effective number of alleles $(\mathrm{Ne}), \mathrm{Nei}$ 's gene diversity $(\mathrm{H})$, and Shannon's information index (I) values and their standard deviations ranged from $1.455 \pm 0.283$ to $1.918 \pm 0.152$, $0.286 \pm 0.145$ to $0.482 \pm 0.058$, and $0.440 \pm 0.198$ to $0.674 \pm 0.062$, respectively.

\section{Genetic Diversity Based on Different Genomic Groups}

Within the 66 accessions of Musa species of the diverse genomic groups assessed with $12 \mathrm{CDDP}$ primers, $\mathrm{Ne}, \mathrm{H}$, and I values spanned from 1.437 to $1.989,0.344$ to 0.497 , and 0.495 to 0.691 (Table 5). The values of these genetic diversity indicators vary in the accessions based on their genomic constitutions involving AA (Ne: $1.775, \mathrm{H}=0.433$, $\mathrm{I}=0.624), \mathrm{AAA}(\mathrm{Ne}=1.437, \mathrm{H}=0.344, \mathrm{I}=0.495)$, AAAA $(\mathrm{Ne}=1.787, \mathrm{H}=0.436, \mathrm{I}=0.627), \mathrm{AAB}(\mathrm{Ne}=1.831$, $\mathrm{H}=0.453, \mathrm{I}=0.645), \mathrm{BB}(\mathrm{Ne}=1.731, \mathrm{H}=0.416$,
$\mathrm{I}=0.617), \mathrm{AB}(\mathrm{Ne}=1.539, \mathrm{H}=0.350, \mathrm{I}=0.535)$, and $\mathrm{ABB}(\mathrm{Ne}=1.771, \mathrm{H}=0.429, \mathrm{I}=0.619)$. For the groups with wild accessions, group AS consisted of 1.990, 0.497, and 0.691 as respective values of $\mathrm{Ne}, \mathrm{H}$, and I, while other diploid accessions with unknown genomic groups had different values of $\mathrm{Ne}, \mathrm{H}$, and $\mathrm{I}$ as in $M$. beccarii $(\mathrm{Ne}=1.747$, $\mathrm{H}=0.427$, and $\mathrm{I}=0.619), M$. coccinea $(\mathrm{Ne}=1.800$, $\mathrm{H}=0.444$, and $\mathrm{I}=0.637)$, and $M$. textilis $(\mathrm{Ne}=1.719$, $\mathrm{H}=0.418$ and $\mathrm{I}=0.609$ ).

The genetic diversity inherent in an AS group was identified to be the highest, with the values of $\mathrm{Ne}, \mathrm{H}$, and I. On the contrary, the genetic diversity in the AAA accessions was determined to be the lowest with $\mathrm{Ne}, \mathrm{H}$, and I indices. The genetic diversity parameters identified in these variable genomic (ploidy) groups were ranked as $\mathrm{AS}>\mathrm{AAB}>\mathrm{AAAA}>\mathrm{AA}>\mathrm{ABB}>$ wild diploidy accessions (M. beccarii, M. coccinea, and M. textilis) with unknown group $>\mathrm{BB}>\mathrm{AB}>\mathrm{AAA}$ from high to low based on polymorphic loci of the selected CDDP primers. The overall mean values of $\mathrm{Ne}, \mathrm{H}$, and $\mathrm{I}$ and their respective 


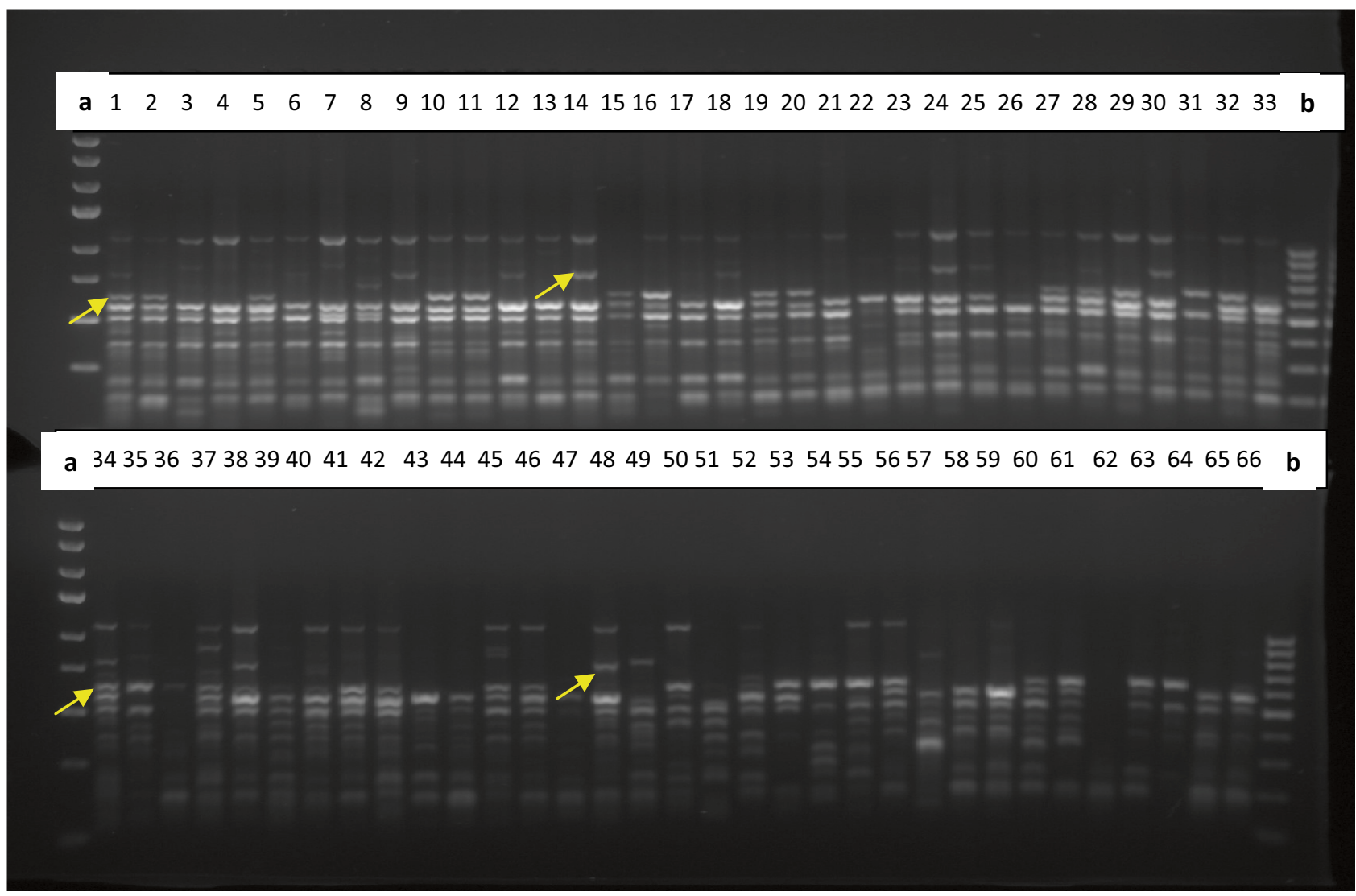

Fig. 1 Amplification profiles of 66 banana and plantain samples using ERF1 primer of CDDP marker gene: $\mathrm{a}=1 \mathrm{~kb}$ step DNA ladder and $b=100 b p$ DNA ladder, Sample order (1-66 from left to right): 1 = "Fougamou 1," 2 = "Obino I'Ewai," $3=$ "Calcutta 4 ," 4 = "Improved Lady Finger," 5 = "Blue Torres Strait Island," $6=$ "Silk," 7 = "Truncata," $8=$ "Cardaba," 9 = "Lidi," $10=$ "Pelipita," 11 = "Pelipita Manjoncho," 12 = "Lai," 13 = "Higa," $14=$ "Pisang Keling," $15=$ "Pisang Lawadin," $16=$ ="Balonkawe," $17=$ "Gros Michel," $18=$ ="Green Red," $19=$ = Plantain no. 3", 20 = "Pata," 21 = "Chinese Cavendish," 22 = "Dwarf Parfitt," 23 = "Hochuchu," 24 = "Umalag," 25 = "Hsein Jen Chiao," 26 = "Mons Mari" (Pedwell), 27 = "Lady Finger" (Nelson), 28 = "Pisang Rajah" (South Johnstone), 29 = "Tani," $30=$ "Pisang Lilin," 31 = "Poteau Geant," 32 = "Pisang Klutuk

standard deviations across the diverse genomic groups were $1.778 \pm 0.158,0.433 \pm 0.061$, and $0.622 \pm 0.070$.

The assessment of genetic variations within and among the different populations of genomic groups revealed that the values of $\mathrm{Ht}, \mathrm{Hs}, \mathrm{G}_{\mathrm{ST}}$, and $\mathrm{Nm}$ identified in different groups of the accessions were genetically diverse and variable depending on the genomes or groups (Table 6). There were ranges in the values of $\mathrm{Ht}(0.350-0.497)$, Hs $(0.345-0.451)$, $\mathrm{G}_{\mathrm{ST}}(0.014-0.094)$, and $\mathrm{Nm}(4.818-35.824)$. Accessions that possess genome AS represented the highest values of $\mathrm{Ht}, \mathrm{Hs}$, $\mathrm{G}_{\mathrm{ST}}$, and $\mathrm{Nm}$, while the lowest ones were associated with the accessions of $\mathrm{AB}$ group. The overall mean values of $\mathrm{Ht}, \mathrm{Hs}$, $\mathrm{G}_{\mathrm{ST}}$, and $\mathrm{Nm}$ across the studied 66 accessions of different
Wulung," 33 = "Garbon 2," 34 = "Zebrina" (G.F), 35 = "Khae" (Phrae), $36=$ "Dole," $37=$ = Wompa," $38=$ "Pisang Palembang," 39 = "Pisang Awak," $40=$ "Williams" (Bell, South Johnstone), 41 = "Plantain no. 17", 42 = "Kluai Tiparot," $43=$ "Tiau Lagada," 44 = "Niyarma Yik," 45 = "Selangor," 46 = "Long Tavoy," 47 = "Malaccenesis," 48 = "Figure Pomme Geante," 49 = "Highgate," 50 = "Borneo," 51 = "Honduras," 52 = "Pome," 53 = "Kunnan," $54=$ Musa beccarii, $55=$ Musa coccinea, $56=$ "JD Yangambi," 57 = Musa textilis, 58 = "Tomolo," $59=$ "Pisang Berlin," 60 = FHIA-23, $61=$ No.110, 62 = "Dwarf Cavendish," 63 = SH-3436-6, 64 = "Lal Velchi," 65 = "Madang" and $66=$ FHIA21 (\#68). Yellow coloured arrows indicate unique/polymorphic bands in some accessions

genomic groups were $0.433 \pm 0.004,0.404 \pm 0.004,0.066$ and 7.113 , respectively. The $\mathrm{G}_{\mathrm{ST}}$ value recorded 0.066 in which $6.57 \%$ was the total genetic divergence among the populations and the remaining $93.43 \%$ was found within the populations.

\section{Dendrogram Analysis of Different Genomic Groups of Musa Species}

A dendrogram analysis of the 66 accessions obtained from UPGMA procedure produced nine major groups at similarity index of 0.814 (Fig. 5). Group I was subdivided into two subgroups, subgroup I (SGI) and subgroup II (SGII). 


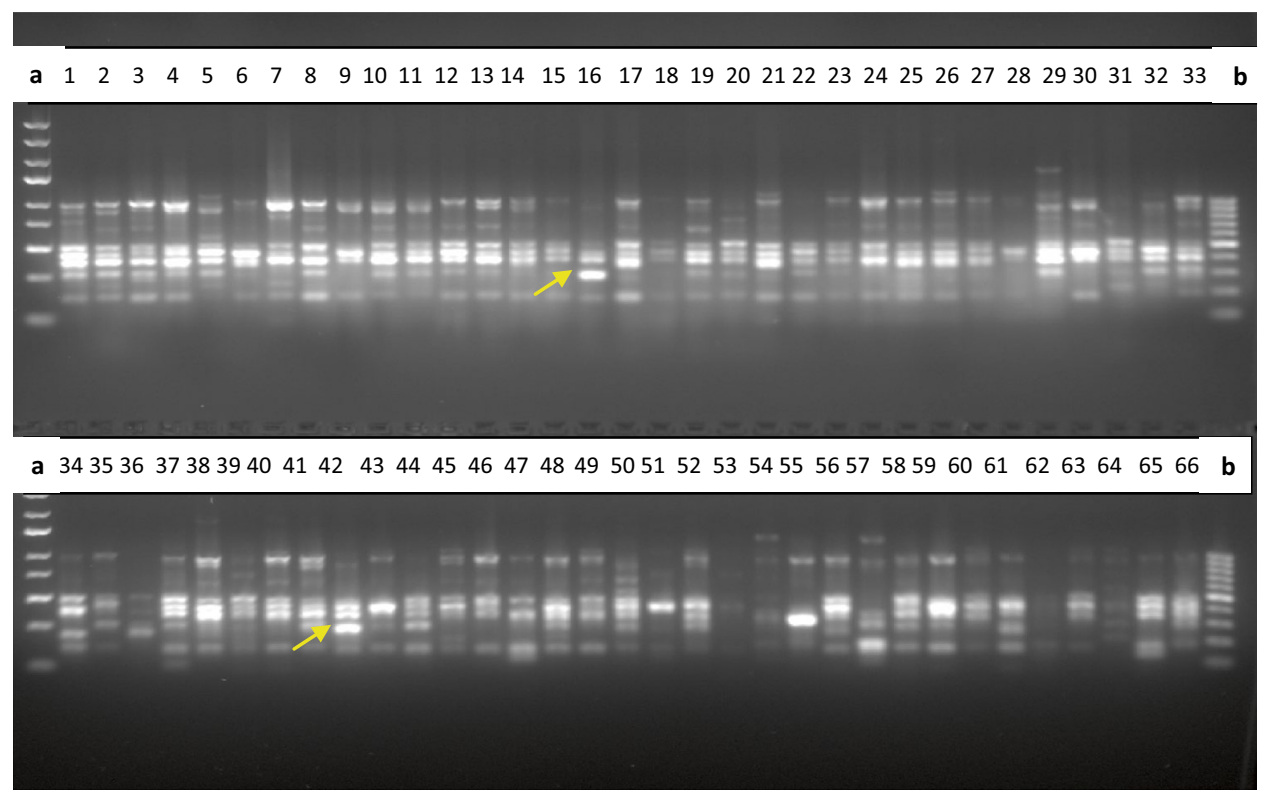

Fig. 2 Amplification profiles of 66 banana and plantain samples using ERF2 primer of CDDP marker gene: $\mathrm{a}=1 \mathrm{~kb}$ step DNA ladder and $b=100 b p$ DNA ladder, Sample order (1-66 from left to right): 1 = "Fougamou 1," 2 = "Obino I'Ewai," $3=$ ="Calcutta 4," 4 = "Improved Lady Finger," 5 = "Blue Torres Strait Island," $6=$ "Silk," 7 = "Truncata," $8=$ "Cardaba," $9=$ = "Lidi," $10=$ "Pelipita," 11 = "Pelipita Manjoncho," 12 = "Lai," 13 = "Higa," 14 = "Pisang Keling," 15 = "Pisang Lawadin," 16 = "Balonkawe," $17=$ "Gros Michel," $18=$ "Green Red," $19=$ "Plantain no. 3", 20 = "Pata," 21 = "Chinese Cavendish," 22 = "Dwarf Parfitt," 23 = "Hochuchu," $24=$ "Umalag," 25 = "Hsein Jen Chiao," 26 = "Mons Mari" (Pedwell), 27 = "Lady Finger" (Nelson), 28 = "Pisang Rajah" (South Johnstone), $29=$ = "Tani," 30 = "Pisang Lilin," 31 = "Poteau Geant," 32 = "Pisang Klutuk

Subgroup I consisted of two accessions, "Fougamou 1" and "Kluai Tiparot," each possessing ABB genomic group, while SGII had four accessions with different genomic groups as "Zebrina" G.F (AA), "Wompa" (AS), "Plantain no. 17" (AAB), and "Pisang Palembang" (AAB). In both subgroups, SGI and SGII, triploids $\mathrm{ABB}$ and $\mathrm{AAB}$ genomes dominated the groups. In group II, two subgroups, SGI and SGII, were respectively identified and in which accessions such as "Mons Mari" (Pedwell: AAA), "Highgate" (AAA), and "Honduras" (BB) were found and their respective genome groups in parentheses in SGI, while SGII had "Lady Finger" Nelson (AAB), "J.D Yangambi" (AAA), "Williams" (Bell South Jones: AAA), "Selangor" (AAA), "Pome" (AAB), "Pisang Awak" (ABB), Musa beccarii (wild diploidy Musa species), FHIA-23 (AAAA), No.110 (AA), and "Borneo" (AA). Triploids AAA dominated SGI of group II, while triploids of different genomic groups (AAB, AAA, and $\mathrm{ABB}$ ) were the most occurring ones, followed by diploids (AA) and tetraploids (AAAA) in SGII of group II. Accessions of different ploidy groups including "Calcutta 4" (AA), "Garbon 2" (AAB), "Blue Torres Strait Island" (ABB),
Wulung," 33 = "Garbon 2," 34 = "Zebrina" (G.F), $35=$ "Khae" (Phrae), $36=$ "Dole," $37=$ = "Wompa," 38 = "Pisang Palembang," 39 = "Pisang Awak," $40=$ "Williams" (Bell, South Johnstone), 41 = "Plantain no. 17", 42 = "Kluai Tiparot," $43=$ "Tiau Lagada," 44 = "Niyarma Yik," 45 = "Selangor," 46 = "Long Tavoy," 47 = "Malaccenesis," 48 = "Figure Pomme Geante," 49 = "Highgate," 50 = "Borneo," 51 = "Honduras," 52 = "Pome," 53 = "Kunnan," 54 = Musa beccarii, 55 = Musa coccinea, 56 = "JD Yangambi," $57=$ Musa textilis, 58 = "Tomolo," $59=$ "Pisang Berlin," 60 = FHIA-23, $61=$ No.110, 62 = "Dwarf Cavendish," 63 = SH-3436-6, 64 = "Lal Velchi," 65 = "Madang" and $66=$ FHIA21 (\#68). Yellow coloured arrows indicate unique/polymorphic bands in some accessions

"Cardaba" (ABB), "Pelitita" (ABB), "Pelitipa Manjoncho" (ABB), "Tani" (BB), and "Pisang Klutuk Wulung" (BB) were detected in group III. In this group III, ABB genomes were the most occurring ones followed by BB. "Pelitita" and "Pelitipa Manjoncho," each with ABB genome, got closely clustered and the same degree of relatedness was observed between accessions "Tani" and "Pisang Klutuk Wulung" that possessed BB group. The B genome dominated this group III, except "Calcutta 4" that possessed AA genomic group. In group IV, "Balonkawe" (ABB), "Poteau Geant" (ABB), "Kunnan" (AB), "Khae" (Phrae: AA), and M. coccinea (wild diploid) were found together. Accessions with B genome were the dominating ones, except "Khae" (Phrae) and $M$. coccinea that had AA and unknown diploid genome, respectively.

Also, group V had two subgroups of SGI ("Obino I'Ewa"-AAB; "Long Tavoy"-AA; "Pata"-ABB; "Plantain no. 3"-AAB; "Madang"-AA; "Pisang Lawadin"-AAB; SH-3436-6-AAAA; "Tomolo"-AA; FHIA21-68-AAAB; and "Lal Velchi"-BB) and SGII ("Dwarf Parfitt"-AAA; "Malaccenesis"-AA; "Tiau Lagada"-AA; and "Niyarma 


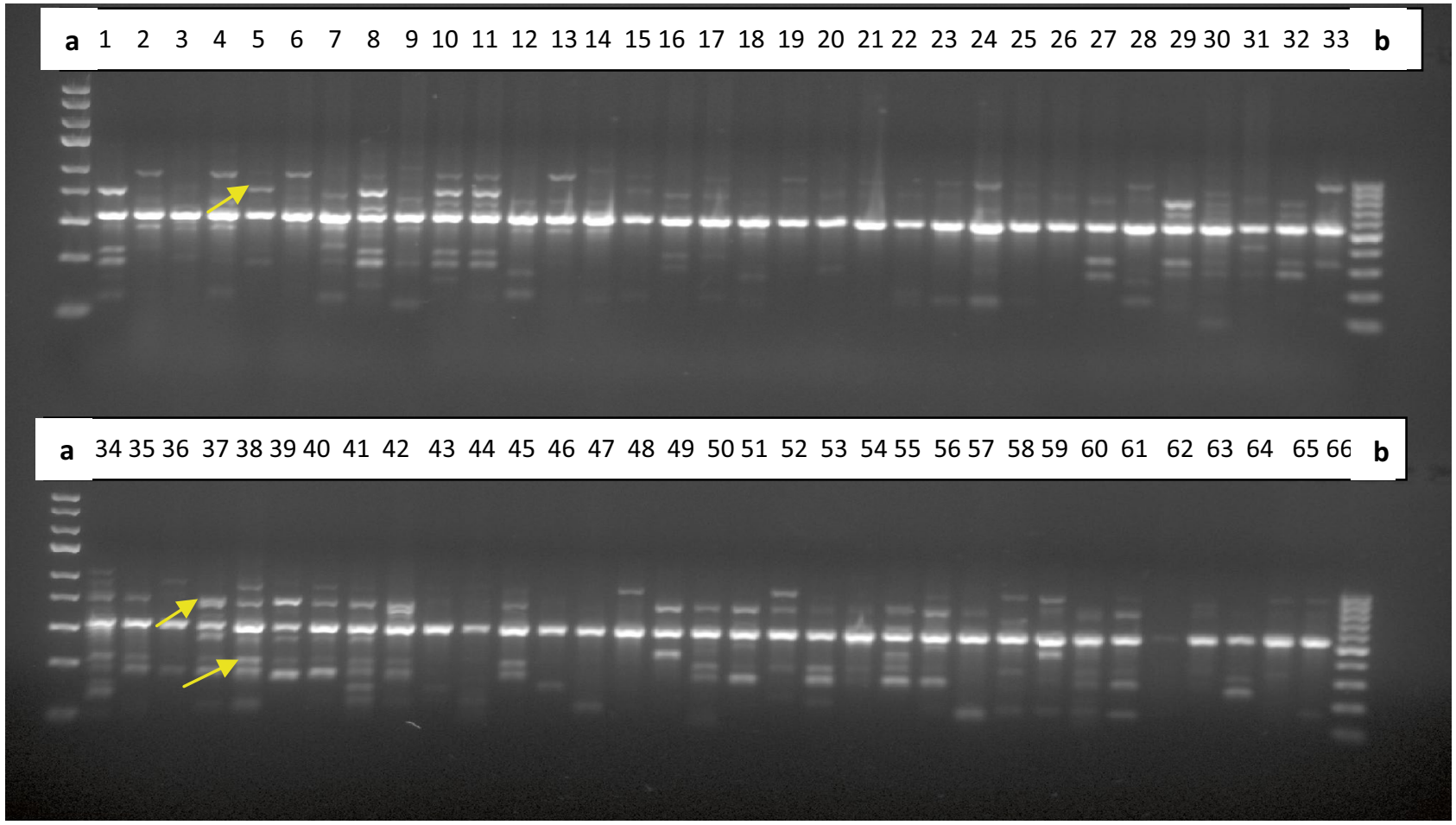

Fig. 3 Amplification profiles of 66 banana and plantain samples using KNOX-1 primer of CDDP marker gene: $\mathrm{a}=1 \mathrm{~kb}$ step DNA ladder and $b=100 b p$ DNA ladder, Sample order (1-66 from left to right): 1 = "Fougamou 1," 2 = "Obino I'Ewai," $3=$ "Calcutta 4," 4 = "Improved Lady Finger," 5 = "Blue Torres Strait Island," $6=$ "Silk," $7=$ "Truncata," $8=$ "Cardaba," $9=$ "Lidi," $10=$ "Pelipita," 11 = "Pelipita Manjoncho," 12 = "Lai," 13 = "Higa," 14 = "Pisang Keling," 15 = "Pisang Lawadin," 16 = "Balonkawe," $17=$ "Gros Michel," $18=$ "Green Red," $19=$ = Plantain no. 3", 20 = "Pata," 21 = "Chinese Cavendish," 22 = "Dwarf Parfitt," 23 = "Hochuchu," $24=$ "Umalag," 25 = "Hsein Jen Chiao," 26 = "Mons Mari" (Pedwell), 27 = "Lady Finger" (Nelson), 28 = "Pisang Rajah" (South Johnstone), $29=$ "Tani," $30=$ "Pisang Lilin," 31 = "Poteau Geant," 32 = "Pisang Klutuk

Yik"-AA). In SGI of group V, different triploids (ABB, $A A B)$ were the most abundant ones followed by diploids (AA, BB) and tetraploids (AAAA, AAAB). Diploid genomic group AA existed in SGII of group $V$, except "Dwarf Parfitt" with triploid (AAA) genomic group. Group VI was further divided into three subgroups, SGI, SGII, and SGIII, respectively. In SGI of group VI, accessions including "Improved Lady Finger" (AAB), "Higa" (AA), "Pisang Berlin" (AA), and "Umalag" (AAA), with A genome dominating but had equal number of diploids (two AA) and triploids (AAB and AAA). SGII consisted of "Silk" (AAB), "Pisang Keling" (AAB), "Gros Michel" (AAA), "Chinese Cavendish" (AAA), "Pisang Rajah" (South Jones: $\mathrm{AAB}$ ), "Figure Pomme Geante" (AAB), "Lidi" (AA), "Lai" (AAA), "Green Red" (AAA), and "Hochuchu" (AAA). The SGII had triploids (AAA) as the most prominent genomic groups followed by other triploids
Wulung," 33 = "Garbon 2," 34 = "Zebrina" (G.F), $35=$ ="Khae" (Phrae), $36=$ "Dole," $37=$ = "Wompa," $38=$ = "Pisang Palembang," 39 = "Pisang Awak," $40=$ "Williams" (Bell, South Johnstone), 41 = "Plantain no. 17", 42 = "Kluai Tiparot," 43 = "Tiau Lagada," 44 = "Niyarma Yik," 45 = "Selangor," 46 = "Long Tavoy," 47 = "Malaccenesis," 48 = "Figure Pomme Geante," 49 = "Highgate," 50 = "Borneo," 51 = "Honduras," 52 = "Pome," 53 = "Kunnan," $54=$ Musa beccarii, $55=$ Musa coccinea, $56=$ "JD Yangambi," 57 = Musa textilis, 58 = "Tomolo," $59=$ "Pisang Berlin," 60 = FHIA-23, $61=$ No.110, 62 = "Dwarf Cavendish," 63 = SH-3436-6, 64 = "Lal Velchi," 65 = "Madang" and $66=$ FHIA21 (\#68). Yellow coloured arrows indicate unique/polymorphic bands in some accessions

(AAB) and a diploid (AA), while SGIII had "Hsein Jen Chiao" (AAA) and "Pisang Lilin" (AA). In groups VII and VIII, "Truncata" (AA) and M. textilis (wild diploid) were respectively identified. Different diploid accessions such as "Dole" (ABB) and "Dwarf Cavendish" (AAA) were contained in group IX.

\section{Principal Component Analysis (PCA) of Different Genomic Groups of Musa Species}

Further analysis of the 66 accessions of bananas and plantains of different genomic groups resolved them into various distinct coordinates (Supplementary file 2: Figure S1). Accessions "Plantain no. 3", "Pisang Lawadin" and "Plantain no. 17," "Blue Strait-Island," "Obino I'Ewa," 


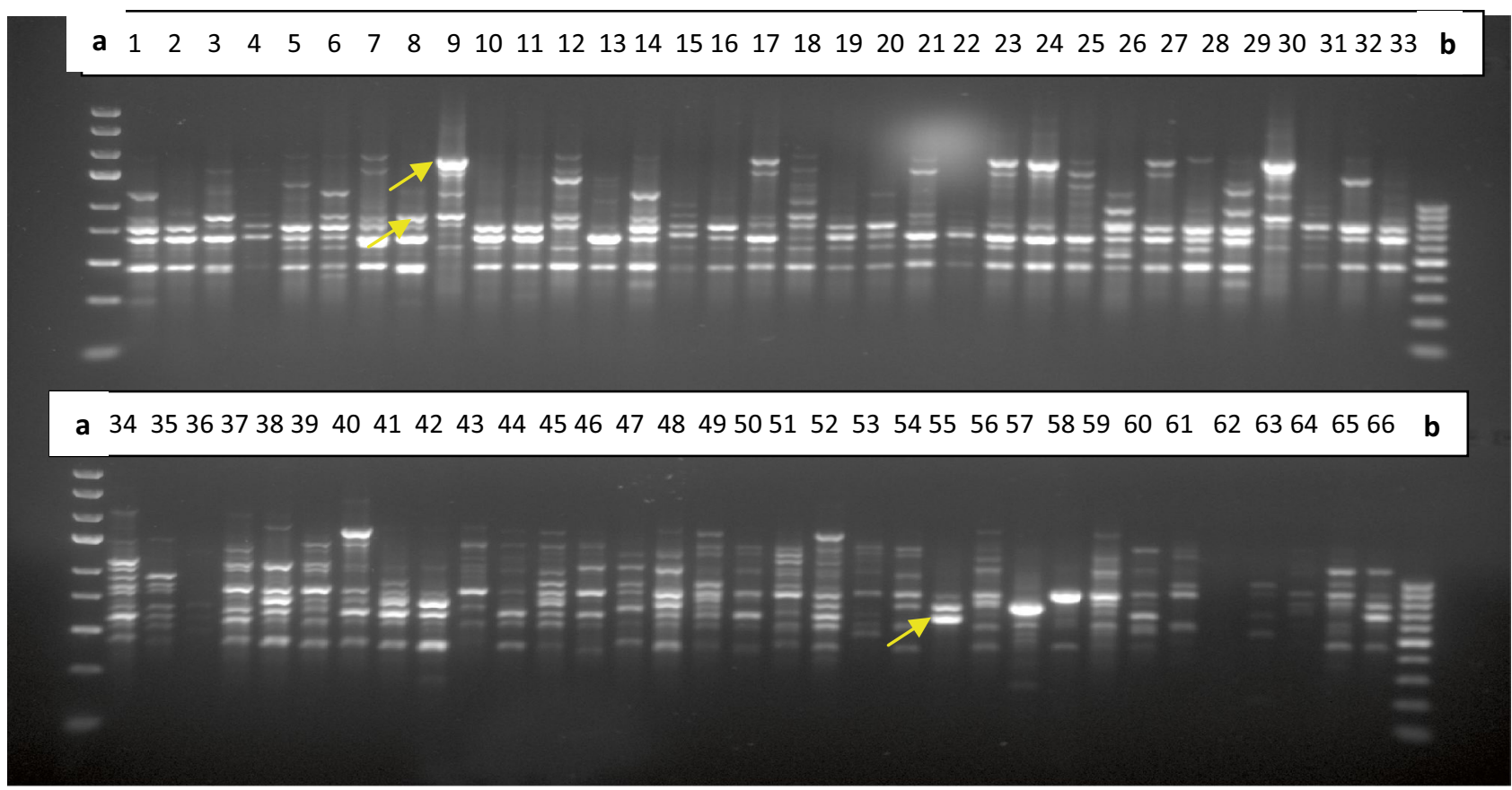

Fig. 4 Amplification profiles of 66 banana and plantain samples using MYB2 primer of CDDP marker gene: $a=1 \mathrm{~kb}$ step DNA ladder and $\mathrm{b}=100 \mathrm{bp}$ DNA ladder, Sample order (1-66 from left to right): 1 = "Fougamou 1," 2 = "Obino I'Ewai," 3 = "Calcutta 4," 4 = "Improved Lady Finger," 5 = "Blue Torres Strait Island," 6 = "Silk," 7 = "Truncata," $8=$ "Cardaba," $9=$ = "Lidi," $10=$ "Pelipita," 11 = "Pelipita Manjoncho," 12 = "Lai," 13 = "Higa," $14=$ "Pisang Keling," $15=$ "Pisang Lawadin," $16=$ ="Balonkawe," $17=$ "Gros Michel," $18=$ "Green Red," $19=$ "Plantain no. 3", 20 = "Pata," 21 = "Chinese Cavendish," 22 = "Dwarf Parfitt," 23 = "Hochuchu," 24 = "Umalag," $25=$ = "Hsein Jen Chiao," 26 = "Mons Mari" (Pedwell), 27 = "Lady Finger" (Nelson), 28 = "Pisang Rajah" (South Johnstone), $29=$ = Tani," 30 = "Pisang Lilin," 31 = "Poteau Geant," 32 = "Pisang Klutuk

"Fougamou1," "Pelipita," "Lal-Velchi," "Tani," "Pisang Klutuk Wulung," "Balonkawe," and "Pelipita Manjoncho" among others were considered plantains due to dominance of "B" genome in all but got closely clustered based on their genomic constitutions. For instance, "Plantain no. 3", "Pisang Lawadin," and "Plantain no. 17" were tightly grouped, and they possessed AAB genomic group. Similar clustering was noted among "Gros Michel," "Truncata," "Long Tavoy," "Malaccenesis," "Chinese Cavendish," "Lidi," "Lai," "Hochuchu," "Hsein-Jen Chiao," "Green Red," "Tiau Lagada," "Highgate," and "Niyarma Yik" among others that had "A" genome as the most occurring one to classify them as bananas. The accessions were either diploid (AA) or triploid (AAA) as contained in "Lidi" and "Chinese Cavendish" accessions, respectively. "Cardaba" and "Hondura," which had $\mathrm{AAB}$ and $\mathrm{BB}$ groups, respectively, did not get clustered to other known $\mathrm{AAB}$ and $\mathrm{BB}$ accessions.
Wulung," 33 = "Garbon 2," 34 = "Zebrina" (G.F), 35 = "Khae" (Phrae), $36=$ ="Dole," $37=$ = "Wompa," $38=$ = "Pisang Palembang," 39 = "Pisang Awak," $40=$ "Williams" (Bell, South Johnstone), 41 = "Plantain no. 17", 42 = "Kluai Tiparot," 43 = "Tiau Lagada," $44=$ "Niyarma Yik," $45=$ "Selangor," $46=$ "Long Tavoy," 47 = "Malaccenesis," 48 = "Figure Pomme Geante," 49 = "Highgate," 50 = "Borneo," 51 = "Honduras," 52 = "Pome," 53 = "Kunnan," $54=$ Musa beccarii, $55=$ Musa coccinea, $56=$ "JD Yangambi," $57=$ Musa textilis, $58=$ "Tomolo," $59=$ "Pisang Berlin," 60 = FHIA-23, $61=$ No.110, $62=$ "Dwarf Cavendish," 63 = SH-3436-6, 64 = "Lal Velchi," 65 = "Madang" and $66=$ FHIA21 (\#68). Yellow coloured arrows indicate unique/polymorphic bands in some accessions

\section{Discussion}

Assessment of genetic diversity, population indices, and polymorphisms among accessions of different genomic groups ranging from diploids to tetraploids is very crucial in Musa species breeding programs, since most programs target establishment of superior ploidy accessions derived from genotypes with favorable traits like resistance to abiotic and biotic factors (Crouch et al. 1999). Conserved DNAderived polymorphisms, which are sequences of gene families that are detectable in multiple copies within the plant genomes, are very efficient and cost-effective molecular techniques that access polymorphisms (variations) in plant species (Collard and Mackill 2009). It has been shown that within functional domains of well-characterized plant genes (involved in responses to abiotic and biotic stress or plant development), the CDDPs can generate informative banding patterns that are utilized for mapping, trait association, 
Table 3 Major allele frequency, number of alleles, gene diversity, and PIC obtained from Musa species using conserved DNA-derived polymorphism primers

\begin{tabular}{lllllr}
\hline CDDP marker & $\begin{array}{l}\text { Major allele } \\
\text { frequency }\end{array}$ & Sample size & $\mathrm{nA}$ & Gene diversity & PIC \\
\hline ERF1 & 0.046 & 66 & 48 & 0.974 & 0.974 \\
ABP1-3 & 0.454 & 66 & 23 & 0.812 & 0.778 \\
ABP1-1 & 0.424 & 66 & 20 & 0.782 & 0.768 \\
ERF2 & 0.152 & 66 & 29 & 0.924 & 0.920 \\
WRKYMusa1a & 0.172 & 66 & 28 & 0.910 & 0.905 \\
KNOX-1 & 0.107 & 66 & 36 & 0.957 & 0.954 \\
MYB2 & 0.106 & 66 & 30 & 0.952 & 0.950 \\
WRKY-R1 & 0.106 & 66 & 45 & 0.963 & 0.962 \\
KNOX-2 & 0.182 & 66 & 29 & 0.920 & 0.915 \\
KNOX1M1a & 0.106 & 66 & 35 & 0.955 & 0.953 \\
MYB1 & 0.061 & 66 & 51 & 0.976 & 0.975 \\
WRKY-F1 & 0.136 & 66 & 47 & 0.966 & 0.965 \\
Total & 2.051 & 792 & 421 & 11.093 & 11.019 \\
Mean & 0.171 & 66 & 35.083 & 0.924 & 0.918 \\
\hline
\end{tabular}

PIC polymorphic information content, $n A$ number of alleles and germplasm genetic diversity studies (Poczai et al. 2013; Collard and Mackill 2009). Due to the inherent efficiency and reliability of using CDDP to easily generate functional

Table 4 Genetic diversity within conserved DNA-derived polymorphism used in accessing genetic diversity of different genomic groups of bananas and plantains

\begin{tabular}{lllccc}
\hline Primer & NPL & PPL & Ne & H & I \\
\hline ERF1 & 66 & \multirow{2}{*}{100} & 1.883 & 0.464 & 0.655 \\
& & & $(0.164)$ & $(0.057)$ & $(0.062)$ \\
ABP1-3 & 66 & 100 & 1.809 & 0.442 & 0.632 \\
& & & $(0.164)$ & $(0.063)$ & $(0.071)$ \\
ABP1-1 & 66 & 100 & 1.819 & 0.452 & 0.642 \\
& & & $(0.174)$ & $(0.073)$ & $(0.081)$ \\
ERF2 & 66 & 100 & 1.747 & 0.419 & 0.607 \\
& & & $(0.197)$ & $(0.077)$ & $(0.088)$ \\
WRKY- & 66 & 100 & 1.908 & 0.472 & 0.664 \\
Musa1a & & & $(0.142)$ & $(0.048)$ & $(0.052)$ \\
KNOX-1 & 66 & 100 & 1.602 & 0.360 & 0.540 \\
& & & $(0.250)$ & $(0.104)$ & $(0.121)$ \\
MYB2 & 65 & 98.48 & 1.760 & 0.420 & 0.606 \\
& & & $(0.224)$ & $(0.093)$ & $(0.114)$ \\
WRKY-R1 & 60 & 89.39 & 1.465 & 0.296 & 0.450 \\
& & & $(0.293)$ & $(0.155)$ & $(0.199)$ \\
KNOX-2 & 66 & 100 & 1.918 & 0.482 & 0.674 \\
& & & $(0.152)$ & $(0.058)$ & $(0.062)$ \\
KNOX1M1a & 66 & 100 & 1.602 & 0.360 & 0.540 \\
& & & $(0.250)$ & $(0.104)$ & $(0.121)$ \\
MYB1 & 65 & 98.48 & 1.781 & 0.427 & 0.613 \\
& & & $(0.229)$ & $(0.092)$ & $(0.112)$ \\
WRKY-F1 & 59 & 89.39 & 1.455 & 0.286 & 0.440 \\
& & & $(0.283)$ & $(0.145)$ & $(0.198)$ \\
\hline
\end{tabular}

Standard deviations are in parentheses

$N P L$ number of polymorphic loci, $P P L$ percentage polymorphic loci, $\mathrm{Ne}$ effective number of alleles, $H$ Nei's gene diversity, I Shannon's information index markers that are associated with a given plant phenotypic expressions, they have been applied in the breeding of different crops (Poczai et al. 2011; Li et al. 2013, 2014; Hajibarat et al. 2015; Jin et al. 2016; Mam et al. 2017; Jiang and Zang 2018), but not yet in banana and plantain crops.

In plants, allelic richness of accessions is an indicator of their genetic diversity endowment and this is usually harnessed by informative molecular markers that detect populations meant for selection, breeding purposes and conservation (Patil et al. 2013; Vinceti et al. 2013). In this study, primers of CDDP markers were retrieved and new ones designed to identify 421 alleles with an average of 35.0833. The alleles ranged from 20 (ABP1) and 51 (MYB1) per primer. In a previous report involving a different crop, Safflower (Cartamus tinctorious L.), 89 alleles were detected among the primers of CDDP marker genes and alleles per primer ranged from 5 (ERF1)-11(WRKYF1) (Talebi et al. 2018). Also, in another investigation involving 21 CDDP primers amplified with twelve date palm samples, a total of 192 scorable bands with an average of 9.1 bands per primer were detected (Sami and Atia 2014). The total number of identifiable alleles, range per primer locus, and their average value were more than the ones detected in previous studies involving different molecular markers of eighteen SSR markers (alleles $=195$, range $=4-18$ and average $=10.8$ (Nyine et al. 2017), and 38 triploid accessions analyzed with 17 microsatellite loci (alleles $=267$, range $=8-24$ and average $=14.00)($ Christelova et al. 2011). Compared with our results, lower values (alleles $=292$, average $=15.4$ ) were generated from the analysis of 70 diploid accessions with 19 microsatellite loci (Christelova et al. 2011). The ranges of allelic counts (1-28) and the frequencies (0.015-0.424) obtained were high, thereby demonstrating the informative nature of these set of primers of the CDDP marker genes in 
Table 5 Genetic diversity indices obtained from 66 accessions of Musa species using conserved DNA-derived polymorphism markers

\begin{tabular}{|c|c|c|c|c|c|}
\hline ITC code & Accession name & Genome group & $\mathrm{Ne}$ & $\mathrm{H}$ & I \\
\hline & & \multicolumn{4}{|l|}{ Diploid: AA } \\
\hline ITC0249 & "Calcutta 4" & AA & 1.849 & 0.459 & 0.652 \\
\hline ITC0393 & "Truncata" & AA & 1.946 & 0.486 & 0.679 \\
\hline ITC0395 & "Lidi" & AA & 1.861 & 0.463 & 0.655 \\
\hline ITC0428 & "Higa" & AA & 1.849 & 0.459 & 0.652 \\
\hline ITC1121 & "Pisang Lilin" & AA & 1.849 & 0.459 & 0.652 \\
\hline ITC0966 & "Zebrina" (G.F) & AA & 1.946 & 0.486 & 0.679 \\
\hline ITC0660 & “Khae” (Phrae) & AA & 1.733 & 0.423 & 0.614 \\
\hline ITC0090 & "Tiau Lagada" & AA & 1.539 & 0.350 & 0.535 \\
\hline ITC0269 & "Niyarma Yik" & AA & 1.615 & 0.381 & 0.569 \\
\hline ITC0093 & "Long Tavoy" & AA & 1.760 & 0.432 & 0.623 \\
\hline ITC0250 & "Malaccenesis" & AA & 1.477 & 0.323 & 0.504 \\
\hline ITC0253 & "Borneo" & AA & 1.882 & 0.469 & 0.662 \\
\hline ITC1187 & "Tomolo" & AA & 1.690 & 0.408 & 0.598 \\
\hline ITC0611 & "Pisang Berlin" & AA & 1.882 & 0.469 & 0.662 \\
\hline ITC0413 & No.110 & AA & 1.760 & 0.432 & 0.623 \\
\hline ITC0254 & "Madang" & AA & 1.760 & 0.432 & 0.623 \\
\hline Total & & & 28.398 & 6.930 & 9.982 \\
\hline \multirow[t]{2}{*}{ Mean } & & & 1.775 & 0.433 & 0.624 \\
\hline & & \multicolumn{4}{|l|}{ Triploid: AAA } \\
\hline ITC0403 & "Lai" & AAA & 1.921 & 0.480 & 0.673 \\
\hline ITC0484 & "Gros Michel" & AAA & 1.837 & 0.456 & 0.648 \\
\hline ITC0485 & "Green Red" & AAA & 1.882 & 0.469 & 0.662 \\
\hline ITC0547 & "Chinese Cavendish" & AAA & 1.760 & 0.432 & 0.623 \\
\hline ITC0548 & "Dwarf Parfitt" & AAA & 1.539 & 0.350 & 0.535 \\
\hline ITC0549 & "Hochuchu" & AAA & 1.861 & 0.463 & 0.655 \\
\hline ITC0550 & "Umalag" & AAA & 1.930 & 0.482 & 0.675 \\
\hline ITC0551 & "Hsein Jen Chiao" & AAA & 1.872 & 0.466 & 0.658 \\
\hline ITC0552 & “Mons Mari” (Pedwell) & AAA & 1.733 & 0.423 & 0.614 \\
\hline ITC0570 & "Williams" (Bell, South Johnstone) & AAA & 1.938 & 0.484 & 0.677 \\
\hline ITC0263 & "Highgate" & AAA & 1.787 & 0.440 & 0.632 \\
\hline ITC1336 & "JD Yangambi" & AAA & 1.787 & 0.440 & 0.632 \\
\hline ITC0002 & "Dwarf Cavendish" & AAA & 1.139 & 0.122 & 0.242 \\
\hline Total & & & 22.986 & 5.506 & 7.926 \\
\hline \multirow[t]{2}{*}{ Mean } & & & 1.437 & 0.344 & 0.495 \\
\hline & & \multicolumn{4}{|c|}{ Tetraploid: AAAA } \\
\hline ITC1060 & "Selangor" & AAAA & 1.986 & 0.497 & 0.690 \\
\hline ITC1265 & FHIA-23 & AAAA & 1.774 & 0.436 & 0.628 \\
\hline ITC1284 & SH-3436-6 & AAAA & 1.600 & 0.375 & 0.562 \\
\hline Total & & & 5.360 & 1.308 & 1.880 \\
\hline \multirow[t]{2}{*}{ Mean } & & & 1.787 & 0.436 & 0.627 \\
\hline & & Triploid: AAB & & & \\
\hline ITC0109 & “Obino I’Ewai" & $\mathrm{AAB}$ & 1.760 & 0.432 & 0.623 \\
\hline ITC0336 & "Improved Lady Finger" & $\mathrm{AAB}$ & 1.837 & 0.456 & 0.648 \\
\hline ITC0348 & "Silk" & $\mathrm{AAB}$ & 1.719 & 0.418 & 0.609 \\
\hline ITC0448 & "Pisang Keling" & $\mathrm{AAB}$ & 1.813 & 0.448 & 0.641 \\
\hline ITC0449 & "Pisang Lawadin" & $\mathrm{AAB}$ & 1.704 & 0.413 & 0.604 \\
\hline ITC0582 & "Lady Finger" (Nelson) & $\mathrm{AAB}$ & 1.849 & 0.459 & 0.652 \\
\hline ITC0587 & "Pisang Rajah" (South Johnstone) & $\mathrm{AAB}$ & 1.837 & 0.456 & 0.648 \\
\hline ITC0017 & "Garbon 2" & $\mathrm{AAB}$ & 1.787 & 0.440 & 0.632 \\
\hline
\end{tabular}


Table 5 (continued)

\begin{tabular}{|c|c|c|c|c|c|c|}
\hline \multirow{2}{*}{$\frac{\text { ITC code }}{\text { ITC0352 }}$} & \multicolumn{2}{|l|}{ Accession name } & \multirow{2}{*}{$\begin{array}{l}\text { Genome group } \\
\text { AAB }\end{array}$} & \multirow{2}{*}{$\begin{array}{l}\mathrm{Ne} \\
1.882\end{array}$} & \multirow{2}{*}{$\begin{array}{l}\mathrm{H} \\
0.469\end{array}$} & \multirow{2}{*}{$\frac{\mathrm{I}}{0.662}$} \\
\hline & "Plantain no. $17 "$ & & & & & \\
\hline ITC0769 & "Figure Pomme Geante" & & $\mathrm{AAB}$ & 1.849 & 0.459 & 0.652 \\
\hline ITC0076 & "Pome" & & $\mathrm{AAB}$ & 1.938 & 0.484 & 0.677 \\
\hline ITC0498 & "Plantain no. 3" & & $\mathrm{AAB}$ & 1.837 & 0.456 & 0.648 \\
\hline ITC0450 & "Pisang Palembang" & & $\mathrm{AAB}$ & 1.996 & 0.499 & 0.692 \\
\hline Total & & & & 23.809 & 5.889 & 8.388 \\
\hline \multirow[t]{2}{*}{ Mean } & & & & 1.831 & 0.453 & 0.645 \\
\hline & & & Diploid: BB & & & \\
\hline ITC1120 & "Tani" & & $\mathrm{BB}$ & 1.903 & 0.474 & 0.667 \\
\hline ITC1587 & "Pisang Klutuk Wulung" & & $\mathrm{BB}$ & 1.800 & 0.444 & 0.637 \\
\hline ITC0247 & "Honduras" & & $\mathrm{BB}$ & 1.774 & 0.436 & 0.677 \\
\hline ITC1588 & "Lal Velchi”" & & $\mathrm{BB}$ & 1.446 & 0.308 & 0.487 \\
\hline Total & & & & 6.922 & 1.663 & 2.468 \\
\hline \multirow[t]{2}{*}{ Mean } & & & & 1.731 & 0.416 & 0.617 \\
\hline & & & Diploid: AB & & & \\
\hline ITC1638 & "Kunnan" & & $\mathrm{AB}$ & 1.539 & 0.350 & 0.535 \\
\hline Total & & & & 1.539 & 0.350 & 0.535 \\
\hline \multirow[t]{2}{*}{ Mean } & & & & 1.539 & 0.350 & 0.535 \\
\hline & & & Triploid: ABB & & & \\
\hline ITC0101 & "Fougamou 1" & & $\mathrm{ABB}$ & 1.912 & 0.477 & 0.670 \\
\hline ITC0338 & "Blue Torres Strait Island" & & $\mathrm{ABB}$ & 1.760 & 0.432 & 0.623 \\
\hline ITC0394 & "Cardaba" & & $\mathrm{ABB}$ & 1.903 & 0.474 & 0.667 \\
\hline ITC0396 & "Pelipita" & & $\mathrm{ABB}$ & 1.912 & 0.477 & 0.670 \\
\hline ITC0397 & "Pelipita Manjoncho" & & $\mathrm{ABB}$ & 1.893 & 0.472 & 0.665 \\
\hline ITC0473 & "Balonkawe" & & $\mathrm{ABB}$ & 1.719 & 0.418 & 0.609 \\
\hline ITC0500 & "Pata" & & $\mathrm{ABB}$ & 1.690 & 0.408 & 0.598 \\
\hline ITC1137 & "Poteau Geant" & & $\mathrm{ABB}$ & 1.600 & 0.375 & 0.562 \\
\hline ITC0767 & "Dole" & & $\mathrm{ABB}$ & 1.339 & 0.253 & 0.421 \\
\hline ITC0213 & "Pisang Awak" & & $\mathrm{ABB}$ & 1.849 & 0.459 & 0.652 \\
\hline ITC0652 & “Kluai Tiparot" & & $\mathrm{ABB}$ & 1.903 & 0.474 & 0.667 \\
\hline Total & & & & 19.479 & 4.720 & 6.804 \\
\hline \multirow[t]{2}{*}{ Mean } & & & & 1.771 & 0.429 & 0.619 \\
\hline & & & Tetraploid: AAAB & & & \\
\hline ITC1332 & & FHIA-21 (\#68) & $\mathrm{AAAB}$ & 1.645 & 0.392 & 0.581 \\
\hline Total & & & & 1.645 & 0.392 & 0.581 \\
\hline Mean & & & & 1.645 & 0.392 & 0.581 \\
\hline \multicolumn{7}{|c|}{ Diploid: AS } \\
\hline ITC1152 & & "Wompa" & AS & 1.990 & 0.497 & 0.691 \\
\hline Total & & & & 1.990 & 0.497 & 0.691 \\
\hline \multirow[t]{2}{*}{ Mean } & & & & 1.990 & 0.497 & 0.691 \\
\hline & & & Diploid: Wild species & & & \\
\hline ITC1070 & & Musa beccarii & beccarii $[$ Ploidy $=2 \mathrm{x}(1)]$ & 1.747 & 0.427 & 0.619 \\
\hline ITC0287 & & Musa coccinea & coccinea $[$ Ploidy $=2 \mathrm{x}(1)]$ & 1.800 & 0.444 & 0.637 \\
\hline ITC1072 & & Musa textilis & textilis $[$ Ploidy $=2 \mathrm{x}(1)]$ & 1.719 & 0.418 & 0.609 \\
\hline Total & & & & 5.265 & 1.290 & 1.864 \\
\hline Mean & & & & 1.755 & 0.430 & 0.621 \\
\hline \multicolumn{2}{|c|}{ Overall Mean } & & & 1.779 & 0.433 & 0.622 \\
\hline \multicolumn{2}{|c|}{ Overall St. Dev } & & & 0.158 & 0.061 & 0.070 \\
\hline
\end{tabular}

$N e$ effective number of alleles, $H$ Nei's gene diversity, IShannon's information index 
Table 6 Genetic differentiation in different genomic groups of 66 accessions of Musa species using conserved DNA-derived polymorphism markers

\begin{tabular}{|c|c|c|c|c|c|c|c|}
\hline ITC code & Accession name & & Genome group & $\mathrm{Ht}$ & Hs & $\mathrm{G}_{\mathrm{ST}}$ & $\mathrm{Nm}$ \\
\hline & & & Diploid: AA & & & & \\
\hline ITC0249 & "Calcutta 4" & & AA & 0.459 & 0.429 & 0.067 & 7.000 \\
\hline ITC0393 & "Truncata" & & AA & 0.486 & 0.476 & 0.020 & 24.000 \\
\hline ITC0395 & "Lidi" & & AA & 0.463 & 0.438 & 0.053 & 8.905 \\
\hline ITC0428 & "Higa" & & AA & 0.459 & 0.444 & 0.033 & 14.500 \\
\hline ITC1121 & "Pisang Lilin" & & AA & 0.459 & 0.447 & 0.026 & 18.786 \\
\hline ITC0966 & “Zebrina” (G.F) & & $\mathrm{AA}$ & 0.486 & 0.459 & 0.055 & 8.526 \\
\hline ITC0660 & "Khae" (Phrae) & & AA & 0.423 & 0.395 & 0.065 & 7.209 \\
\hline ITC0090 & "Tiau Lagada" & & $\mathrm{AA}$ & 0.350 & 0.308 & 0.121 & 3.644 \\
\hline ITC0269 & "Niyarma Yik" & & AA & 0.381 & 0.336 & 0.118 & 3.732 \\
\hline ITC0093 & “Long Tavoy” & & AA & 0.432 & 0.368 & 0.148 & 2.890 \\
\hline ITC0250 & "Malaccenesis" & & $\mathrm{AA}$ & 0.323 & 0.308 & 0.047 & 10.245 \\
\hline ITC0253 & "Borneo" & & AA & 0.469 & 0.457 & 0.026 & 18.842 \\
\hline ITC1187 & "Tomolo" & & $\mathrm{AA}$ & 0.408 & 0.390 & 0.046 & 10.409 \\
\hline ITC0611 & "Pisang Berlin" & & $\mathrm{AA}$ & 0.469 & 0.450 & 0.040 & 11.888 \\
\hline ITC0413 & No.110 & & AA & 0.432 & 0.407 & 0.057 & 8.282 \\
\hline ITC0254 & "Madang" & & AA & 0.432 & 0.418 & 0.033 & 14.512 \\
\hline Total & & & & 6.930 & 6.529 & 0.955 & 173.37 \\
\hline \multirow[t]{2}{*}{ Mean } & & & & 0.433 & 0.408 & 0.060 & 10.836 \\
\hline & & & Triploid: AAA & & & & \\
\hline ITC0403 & "Lai" & & AAA & 0.480 & 0.455 & 0.051 & 9.251 \\
\hline ITC0484 & "Gros Michel" & & AAA & 0.456 & 0.450 & 0.013 & 38.241 \\
\hline ITC0485 & "Green Red" & & AAA & 0.469 & 0.384 & 0.182 & 2.249 \\
\hline ITC0547 & "Chinese Cavendish" & & AAA & 0.432 & 0.387 & 0.104 & 4.299 \\
\hline ITC0548 & "Dwarf Parfitt" & & AAA & 0.350 & 0.335 & 0.043 & 11.151 \\
\hline ITC0549 & "Hochuchu" & & AAA & 0.463 & 0.423 & 0.086 & 5.297 \\
\hline ITC0550 & "Umalag" & & AAA & 0.482 & 0.468 & 0.029 & 16.500 \\
\hline ITC0551 & "Hsein Jen Chiao" & & AAA & 0.466 & 0.439 & 0.058 & 8.147 \\
\hline ITC0552 & "Mons Mari” (Pedwell) & & AAA & 0.423 & 0.407 & 0.037 & 13.123 \\
\hline ITC0570 & "Williams" (Bell, South Johnstone) & & AAA & 0.484 & 0.457 & 0.057 & 8.326 \\
\hline ITC0263 & "Highgate" & & AAA & 0.440 & 0.412 & 0.064 & 7.367 \\
\hline ITC1336 & “JD Yangambi” & & AAA & 0.440 & 0.397 & 0.098 & 4.586 \\
\hline ITC0002 & "Dwarf Cavendish" & & AAA & 0.122 & 0.117 & 0.048 & 9.904 \\
\hline Total & & & & 5.506 & 5.129 & 0.870 & 138.441 \\
\hline \multirow[t]{2}{*}{ Mean } & & & & 0.424 & 0.395 & 0.067 & 10.649 \\
\hline & & & AAAA & & & & \\
\hline ITC1060 & & "Selangor" & AAAA & 0.497 & 0.475 & 0.043 & 11.217 \\
\hline ITC1265 & & FHIA-23 & AAAA & 0.436 & 0.413 & 0.053 & 9.000 \\
\hline ITC1284 & & SH-3436-6 & AAAA & 0.375 & 0.335 & 0.107 & 4.192 \\
\hline Total & & & & 1.308 & 1.224 & 0.202 & 24.409 \\
\hline \multirow[t]{2}{*}{ Mean } & & & & 0.436 & 0.408 & 0.067 & 8.136 \\
\hline & & & $\mathrm{AAB}$ & & & & \\
\hline ITC0109 & & "Obino I’Ewai" & $\mathrm{AAB}$ & 0.432 & 0.406 & 0.061 & 7.714 \\
\hline ITC0336 & & "Improved Lady Finger" & $\mathrm{AAB}$ & 0.456 & 0.433 & 0.050 & 9.455 \\
\hline ITC0348 & & "Silk" & $\mathrm{AAB}$ & 0.418 & 0.366 & 0.125 & 3.487 \\
\hline ITC0448 & & "Pisang Keling" & $\mathrm{AAB}$ & 0.448 & 0.414 & 0.076 & 6.050 \\
\hline ITC0449 & & "Pisang Lawadin" & $\mathrm{AAB}$ & 0.413 & 0.367 & 0.113 & 3.924 \\
\hline ITC0498 & & "Plantain no. 3" & $\mathrm{AAB}$ & 0.456 & 0.424 & 0.069 & 6.759 \\
\hline ITC0582 & & "Lady Finger" (Nelson) & $\mathrm{AAB}$ & 0.459 & 0.435 & 0.052 & 9.143 \\
\hline ITC0587 & & $\begin{array}{l}\text { "Pisang Rajah" (South John- } \\
\text { stone) }\end{array}$ & $\mathrm{AAB}$ & 0.456 & 0.401 & 0.121 & 3.628 \\
\hline ITC0017 & & "Garbon 2" & $\mathrm{AAB}$ & 0.440 & 0.418 & 0.052 & 9.121 \\
\hline
\end{tabular}


Table 6 (continued)

\begin{tabular}{|c|c|c|c|c|c|c|}
\hline ITC code & & Genome group & $\mathrm{Ht}$ & Hs & $\mathrm{G}_{\mathrm{ST}}$ & $\mathrm{Nm}$ \\
\hline ITC0450 & "Pisang Palembang" & $\mathrm{AAB}$ & 0.499 & 0.481 & 0.035 & 13.694 \\
\hline ITC0352 & "Plantain no. 17" & $\mathrm{AAB}$ & 0.469 & 0.438 & 0.066 & 7.103 \\
\hline ITC0769 & "Figure Pomme Geante" & $\mathrm{AAB}$ & 0.459 & 0.422 & 0.082 & 5.636 \\
\hline ITC0076 & "Pome" & $\mathrm{AAB}$ & 0.484 & 0.467 & 0.036 & 13.556 \\
\hline Total & & & 5.889 & 5.470 & 0.938 & 90.148 \\
\hline \multirow[t]{2}{*}{ Mean } & & & 0.453 & 0.421 & 0.072 & 6.934 \\
\hline & & Diploid: BB & & & & \\
\hline ITC1120 & “Tani” & $\mathrm{BB}$ & 0.474 & 0.423 & 0.109 & 4.079 \\
\hline ITC1587 & 'Pisang Klutuk Wulung' & BB & 0.444 & 0.403 & 0.093 & 4.870 \\
\hline ITC0247 & "Honduras" & $\mathrm{BB}$ & 0.436 & 0.417 & 0.045 & 10.652 \\
\hline ITC1588 & "Lal Velchi" & $\mathrm{BB}$ & 0.308 & 0.281 & 0.090 & 5.051 \\
\hline Total & & & 1.663 & 1.523 & 0.337 & 24.652 \\
\hline \multirow[t]{2}{*}{ Mean } & & & 0.416 & 0.381 & 0.084 & 6.163 \\
\hline & & Diploid: AB & & & & \\
\hline ITC1638 & "Kunnan" & $\mathrm{AB}$ & 0.350 & 0.345 & 0.014 & 35.824 \\
\hline Total & & & 0.350 & 0.345 & 0.014 & 35.824 \\
\hline \multirow[t]{2}{*}{ Mean } & & & 0.350 & 0.345 & 0.014 & 35.824 \\
\hline & & Triploid: ABB & & & & \\
\hline ITC0101 & "Fougamou 1" & $\mathrm{ABB}$ & 0.477 & 0.427 & 0.105 & 4.254 \\
\hline ITC0338 & "Blue Torres Strait Island" & $\mathrm{ABB}$ & 0.432 & 0.387 & 0.104 & 4.299 \\
\hline ITC0394 & "Cardaba" & $\mathrm{ABB}$ & 0.474 & 0.433 & 0.088 & 5.203 \\
\hline ITC0396 & "Pelipita" & $\mathrm{ABB}$ & 0.477 & 0.459 & 0.037 & 12.857 \\
\hline ITC0397 & "Pelipita Manjoncho" & $\mathrm{ABB}$ & 0.472 & 0.447 & 0.052 & 9.174 \\
\hline ITC0473 & "Balonkawe" & $\mathrm{ABB}$ & 0.418 & 0.400 & 0.044 & 10.846 \\
\hline ITC0500 & "Pata" & $\mathrm{ABB}$ & 0.408 & 0.357 & 0.125 & 3.500 \\
\hline ITC1137 & "Poteau Geant" & $\mathrm{ABB}$ & 0.375 & 0.347 & 0.075 & 6.182 \\
\hline ITC0767 & "Dole" & $\mathrm{ABB}$ & 0.253 & 0.246 & 0.030 & 16.206 \\
\hline ITC0213 & "Pisang Awak" & $\mathrm{ABB}$ & 0.459 & 0.447 & 0.026 & 18.786 \\
\hline ITC0652 & "Kluai Tiparot" & $\mathrm{ABB}$ & 0.474 & 0.440 & 0.073 & 6.318 \\
\hline Total & & & 4.720 & 4.389 & 0.759 & 97.625 \\
\hline \multirow[t]{2}{*}{ Mean } & & & 0.429 & 0.399 & 0.069 & 8.875 \\
\hline & & Diploid: AS & & & & \\
\hline ITC1152 & "Wompa" & AS & 0.497 & 0.451 & 0.094 & 4.818 \\
\hline Total & & & 0.497 & 0.451 & 0.094 & 4.818 \\
\hline \multirow[t]{2}{*}{ Mean } & & & 0.497 & 0.451 & 0.094 & 4.818 \\
\hline & & Tetraploid: AAAB & & & & \\
\hline ITC1332 & FHIA-21 (\#68) & AAAB & 0.392 & 0.370 & 0.057 & 8.286 \\
\hline Total & & & 0.392 & 0.370 & 0.057 & 8.286 \\
\hline \multirow[t]{2}{*}{ Mean } & & & 0.392 & 0.370 & 0.057 & 8.286 \\
\hline & & Diploid: Wild species & & & & \\
\hline ITC1070 & Musa beccarii & beccarii $[$ Ploidy = 2x (1)] & 0.427 & 0.422 & 0.013 & 37.200 \\
\hline ITC0287 & Musa coccinea & coccinea $[$ Ploidy $=2 \mathrm{x}(1)]$ & 0.444 & 0.427 & 0.040 & 12.145 \\
\hline ITC1072 & Musa textilis & textilis $[$ Ploidy $=2 \mathrm{x}(1)]$ & 0.418 & 0.393 & 0.060 & 7.787 \\
\hline Total & & & 1.290 & 1.242 & 0.113 & 57.132 \\
\hline Mean & & & 0.430 & 0.414 & 0.038 & 19.044 \\
\hline Overall Mean & & & 0.433 & 0.404 & 0.066 & 7.113 \\
\hline Overall St. Dev & & & 0.004 & 0.004 & & \\
\hline
\end{tabular}

$H t$ total gene diversity, $H s$ gene diversity within population, $G_{S T}$ coefficient of gene differentiation, $N m$ estimate of gene flow from $G_{\mathrm{ST}}$ or Gcs. E.g., $N m 0.5\left(1-\mathrm{G}_{\mathrm{ST}}\right) / \mathrm{G}_{\mathrm{ST}}$ 


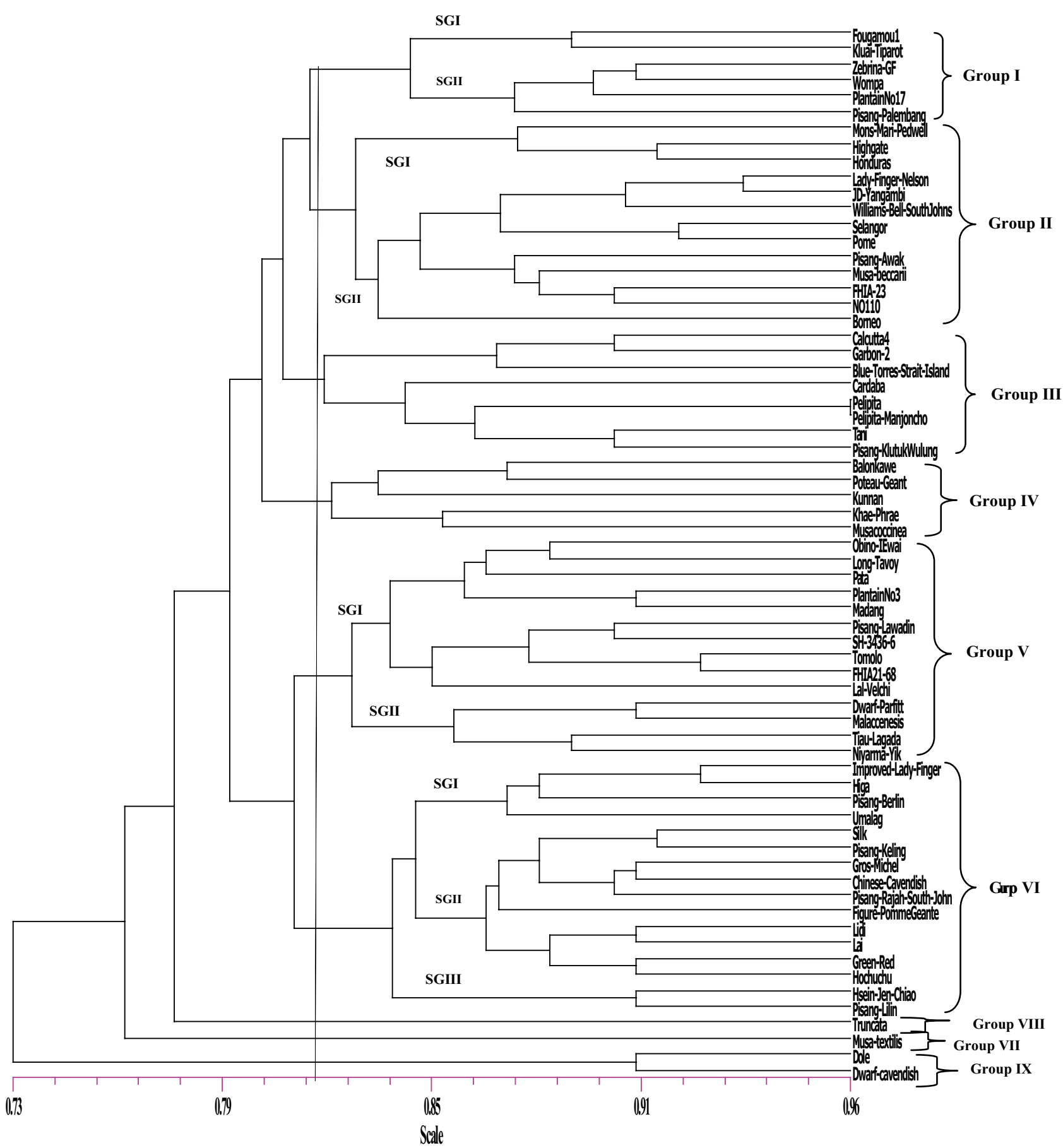

Fig. 5 Dendrogram resolution of 66 accessions of Musa species using conserved DNA-derived polymorphism (CDDP) marker genes. $\mathrm{SG}=$ subgroup

Musa species. Studies in other crops using different molecular markers revealed that allelic richness has been established as an indicator of genetic diversity and that it is majorly used to assess populations purely meant for conservation and breeding purposes (Patil et al. 2013; Vinceti et al. 2013). In this study, the additionally designed primers of CDDP markers that had less than $60 \%$ GC content either failed woefully or did not amplify well, thereby confirming the higher percentage of GC content as a favorable factor for successful amplifications of CDDP primers in plants (Collard and Mackill 2009).

The primers of the CDDP markers demonstrated high level of PIC (0.918) ranging from 0.768 to 0.975 , whereas 0.870 with a range of 0.530 to 0.950 , were obtained as PIC and 
mean respectively, from SSR markers (Nyine et al. 2017). Also, in a study of 38 triploid accessions analyzed with 19 microsatellite markers, PIC of $0.850(0.760-0.942)$ was obtained (Christelova et al. 2011; Changadeya et al. 2012). In comparison with our findings, lower value of PIC of $0.827(0.625-0.936)$ was generated from the analysis of 70 diploid accessions with 19 microsatellite loci (Christelova et al. 2011). This shows how informative, discriminatory, and efficient the CDDP markers may be when compared to SSR, ISSR, and RAPD markers. The major allele frequency of $0.220(0.100-0.450)$ generated from SSR markers (Nyine et al. 2017) was found similar to the ones (0.171; 0.046-0.454) obtained in this study, and this shows the effectiveness of CDDP markers in exploring the allelic richness of this vital crop. The identified gene diversity of 0.924 (0.782-0.976) was higher than the previously reported ones obtained with SSR markers (Poerba and Ahmad 2010; Changadeya et al. 2012; Nyine et al. 2017). The identified PIC was high enough and contributed to the resolution of even the closest accessions and genomic groups. Furthermore, MYB1 primer of CDDP markers displayed the highest PIC; therefore, it is regarded as the most informative one and has been implicated in secondary metabolism, abiotic, and biotic stresses, as well as cellular morphogenesis (Stracke et al. 2001; Jiang et al. 2004). Also, these novel primers generated unique alleles from the different genomic accessions as earlier reported (Youssef et al. 2011).

We obtained high PPL of 100 (89.39-100\%) and that depicts high efficacious nature of the CDDP markers used. The range of PPL generated is highest when compared to the ones obtained from different marker systems as contained in RAPD (44.44-100\%), ISSR (66.66-100\%), and DAMD (66.66-100\%) (Lamare and Rao 2015). High polymorphism identifiable by molecular markers has been shown to rely on the presence of repeated sequences of $\mathrm{AC}, \mathrm{CA}, \mathrm{AG}$, and GA (Ghalmi et al. 2010). From the 12 CDDP markers, KNOX-2 was shown to be the most genetically abundant one in this crop species with values of NPL, PPL, Ne, H, and I, while the WRKY-F1 had the least of genetic diversity abundance. The KNOX-2 has been reported to be associated with homeobox genes that function as transcription factors with a unique homeodomain (Nagasaki et al. 2001), while WRKY-F1 is linked to transcription factor for developmental and physiological roles in plants (Xie et al. 2005).

Populations having high genetic diversity of neutral markers and alleles could be utilized as suitable candidates for high adaptive variation, fitness, and conservation (Van et al. 2012; Ilves et al. 2013). Genetic indices including Ne, H, and I have been considered very crucial in the analysis of genetic diversity in several plants since they measure degree of genetic diversity of species (Hamilton 2009; Freeland et al. 2011). Within the populations of different genomic groups of Musa accessions investigated, we found that the
$\mathrm{Ne}, \mathrm{H}$, and I were highest in "Wompa" with AS followed by $\mathrm{AAB}$, while the least diverse was the AAA population. The narrow genetic base in this A genome accession could be responsible for its susceptibility to different abiotic and biotic stressors. The higher genetic diversity observed in this wild accession, "Wompa," has been reported in other invasive species of other crops (Kelager et al. 2013).

It is noteworthy that conservation efforts of biodiversity focus on selecting accessions of crops with genetic reservoir for potential and proven desirable adaptability, especially, under the influence of abiotic and biotic factors (Bilz et al. 2011). Using CDDP data matrix, all the assessed population and genetic parameters including $\mathrm{Ht}, \mathrm{Hs}, \mathrm{G}_{\mathrm{ST}}$, and $\mathrm{Nm}$ were found to be high in all the accessions studied. But compared to other accessions, "Wompa" with AS genomic group had the highest with $\mathrm{Ht}, \mathrm{Hs}, \mathrm{G}_{\mathrm{ST}}$, and $\mathrm{Nm}$ values as 0.497 , $0.451,0.094$, and 4.818 , followed by AAB that had 0.453 , $0.421,0.072$, and 6.934 as respective indices of $\mathrm{Ht}, \mathrm{Hs}, \mathrm{G}_{\mathrm{ST}}$, and $\mathrm{Nm}$. The $\mathrm{AB}$ group had the least values $(\mathrm{Ht}=0.350$, $\mathrm{Hs}=0.345, \mathrm{G}_{\mathrm{ST}}=0.014$, and $\left.\mathrm{Nm}=35.824\right)$. Generally, the population genetic structure values $(\mathrm{Ht}=0.433 \pm 0.004$, $\mathrm{Hs}=0.404 \pm 0.004, \mathrm{G}_{\mathrm{ST}}=0.066$, and $\mathrm{Nm}=7.113$ ) identified in this study are high and demonstrate the usefulness of the markers. Genetic diversities within and between populations enhance selection of populations that are responsible for the majority of the existing variations. If genetic diversities are found mostly within a population, then it implies that fewer populations are required to protect and maintain the overall differences in the accessions or populations. However, if genetic diversities are kept majorly between populations, then a higher number of populations should be prioritized for protection and utilization. According to Nei (Nei 1978), $G_{\mathrm{ST}}$ is classified as low when its value is $<0.05$, medium when its value is $0.05<\mathrm{G}_{\mathrm{ST}}<0.15$, and high when $\mathrm{G}_{\mathrm{ST}}>0.15$. In this study, the $\mathrm{G}_{\mathrm{ST}}$ is 0.066 and that signifies that $6.57 \%$ is among the population and $93.43 \%$ within the population. The higher percentage of genetic diversity within populations has been demonstrated in other plants (Yang 2009; Qu 2013). The distribution of genetic diversity also plays an important role in species conservation (Barrett and Kohn 1991; Ge et al. 1998; Millar and Libby 1991). The high level of $\mathrm{Nm}$ recorded is a potentially viable parameter capable of inducing huge genetic divergences noted in these accessions as earlier asserted in another crop (Jin et al. 2016).

The dendrogram analysis of the studied accessions of different ploidy groups using CDDP marker systems revealed nine principal clusters that exhibited unique topology with some similarities. In a previous study involving different marker systems, SSR, AFLP, and RAPD, five clusters were detected (Sami and Atia 2014), and this could be attributable to the nature of the markers and the number of accessions used. Some of the different genomic groups 
were correctly resolved, while some including those with mixed ploidy groups got clustered together based on their genetic similarity possessed from their progenitors, $M$. acumminata (A genome) and M. balbisiana (B genome). For instance, "Pelitita" and "Pelitipa Manjoncho," each with ABB genome, closely clustered and the same relatedness was found between accessions "Tani" and "Pisang Klutuk Wulung" that possessed BB group. The B genome dominates group III, except "Calcutta 4" that possesses AA genomic group, but was found in the same group due to possible existence of ancestral linkage as previously reported (Brown et al. 2009). It has been reported that the farther away accessions are from one another, the more the possibility of acquiring wider genetic diversity, which also identifies their locations on clusters (Skroch and Nienhuis 1995). Accessions "Truncata" and M. textilis were the most genetically isolated as evidenced in their existing respective groups followed by "Dole" and "Dwarf Cavendish" that were found clustering only in one group. Most of the accessions of different genomic groups were located in the major groups with other subgroups to demonstrate the level of relatedness among them as earlier reported using ISSR markers (Silva et al. 2016). "Zebrina" G.F., M. acuminata with AA genomic group, grouped together with $M$. schizocarpa with AS genome and this collaborates with a previous report (Christelova et al. 2011). Some Musa diploid wild species, including $M$. beccarii and M. coccinea, whose genomic constitutions were yet to be known, got closely clustered with A genome, suggesting that they belong to A genomic group. This type of close relationship has been shown between M. acuminata (A genome) and Rhodochlamys (Christelova et al. 2011; Li et al. 2010; Liu et al. 2010). In group II, the diploid, triploids, and tetraploids formed two distinct but closely related subgroups, thereby demonstrating support for the hypothesis of production of unreduced triploid $(3 \mathrm{~N})$ and reduced haploid $(\mathrm{N})$ gametes during meiotic events in the tetraploid progenitors (Ssali et al. 2010). The marker, CDDP, facilitated discrimination between subgroups and genomic constitutions, although some could not be resolved due to their common ancestral lineage and narrowed genetic polymorphisms occasioned by vegetative propagation cycles as earlier reported (Christelova et al. 2011).

Further analysis of the 66 accessions of bananas and plantains of different genomic groups resolved them into various distinct coordinates based on bananas and plantains as well as different genomic constitutions. Accessions "Plantain no. 3", "Pisang Lawadin" and "Plantain no. 17", "Blue Strait-Island," "Obino I'Ewa," "Fougamou 1," "Pelipita," "Lal-Velchi," "Tani," "Pisang Klutuk Wulung", "Balonkawe," and "Pelipita Manjoncho" among others are plantains due to dominance of "B" genome in all but got clustered closely depending on their genomic constitutions. The association of some "A" could be attributable to previous misclassification of their ploidy groups and due to ancestral lineage. For instance, three plantain accessions (Plantain no. 3, "Pisang Lawadin," and "Plantain no. 17") were tightly grouped and they possessed AAB genomic group. Similar clustering was noted in banana accessions ("Gros Michel," "Truncata," "Long Tavoy," "Malaccenesis," "Chinese Cavendish," "Lidi," "Lai," "Hochuchu," "Hsein-Jen Chiao," "Green Red," "Tiau Lagada," "Highgate," "Niyarma Yik" among others) that have "A" genome as the dominating one. The accessions were either diploid (AA) or triploid (AAA) as contained in "Lidi" and "Chinese Cavendish" accessions, respectively, and this type of homogenomic grouping has been reported (Brown et al. 2009; Rajamanickam and Rajmohan 2012). "Cardaba" and "Hondura," which have AAB and BB groups, respectively, did not cluster with other known $\mathrm{AAB}$ and $\mathrm{BB}$ accessions.

\section{Conclusion}

The set of primers derived from CDDP markers exhibited high resolving potential and discriminatory capability based on high PIC values, and these primers may be employed in breeding programs to facilitate assessment of genetic diversity, population, and allelic richness of accessions of Musa species. The CDDP markers were identified to be more efficient and informative in assessing genetic diversity, and population potentials among Musa species, compared to other gel-based molecular markers including ISSR, and RAPD as demonstrated by high values of PIC, PPL, Ne, H, I, Ht, $\mathrm{Hs}, \mathrm{Nm}$, and other genetic indices obtained. The results suggest that AS genomic group is the most genetically diverse among the genomic groups. Dendrogram analysis of the accessions with variable genomic constitutions revealed better clustering of the accessions compared to PCA. Unique alleles identified in some of the accessions could be associated with useful phenotypic traits since the CDDP markers are functionally genebased markers that are phenotypically linked to characters of abiotic and biotic stressors. Therefore, these selected primers of CDDP could serve as useful tools for selection of good hybrids for improved breeding and germplasm conservation. However, the accessions with high genetic indices as a result of variable combination events may be harnessed and utilized as suitable training populations in Musa species breeding programs. 
Supplementary Information The online version contains supplementary material available at https://doi.org/10.1007/s11105-021-01290-x.

Acknowledgements We also thank International Transit Center (ITC), Kasteelpark Arenberg 13 bus 2455, 3001 Leuven, Belgium, for providing the different genomic groups of bananas and plantains used in this project.

Author Contribution All authors were involved in the designing of the project. DOI, GA, and GNU conceptualized the project and did the literature search strategy. GNU and GA were involved in the funding acquisition. DOI, OCI, and AAO did the DNA extraction, PCR, and data scoring. DOI did the analyses. DOI developed the first draft. All authors read the manuscript and approved the final copy of it.

Funding Author GNU received research grants (with grant number HRD-1438902) from National Science Foundation (NSF) to conduct this study.

Data Availability All data generated during this study are included in this published article (and its supplementary information files).

\section{Declarations}

Research Involving Humans and Animals This work does not involve living animals and no consent is needed.

Conflict of Interest The authors declare that they have no competing interests.

Open Access This article is licensed under a Creative Commons Attribution 4.0 International License, which permits use, sharing, adaptation, distribution and reproduction in any medium or format, as long as you give appropriate credit to the original author(s) and the source, provide a link to the Creative Commons licence, and indicate if changes were made. The images or other third party material in this article are included in the article's Creative Commons licence, unless indicated otherwise in a credit line to the material. If material is not included in the article's Creative Commons licence and your intended use is not permitted by statutory regulation or exceeds the permitted use, you will need to obtain permission directly from the copyright holder. To view a copy of this licence, visit http://creativecommons.org/licenses/by/4.0/.

\section{References}

Abarshi MM, Mohammed IU, Wasswa P, Hillocks RJ, Holta J, Legg JP, Seal SE, Maruthi MN (2010) Optimization of diagnostic RT-PCR protocols and sampling procedures for the reliable and cost-effective detection of Cassava brown streak virus. J Virol Methods 163:353-359

Anai T, Miyata M, Kosemura S, Yamamura S, Tsuge T, Matsui M, Uchida H, Hasegawa K (1997) Comparison of ABP1 primary sequences from monocotyledonous and dicotyledonous species. J Plant Physiol 151(4):446-449

Barrett S, Kohn J (1991) Genetic and evolutionary consequences of small population size in plants: implications for conservation. In: Falk DA, Holsinger KE (eds) Genetics and conservation of rare plants. Oxford University Press, New York, pp 3-30

Bhat KV, Jarret RL, Rana RS (1995) DNA profiling of banana and plantain cultivars using random amplified polymorphic DNA (RAPD) and restriction fragment length polymorphism (RFLP) markers. Electrophoresis 16(1):1736-1745
Bhuiyan FR, Camposa NA, Swennen R, Carpentier S (2020) Characterizing fruit ripening in plantain and Cavendish bananas: a proteomics approach. J Proteomics 214:103632

Bilz M, Kell S, Maxted N, Lansdown RV (2011) European red list of vascular plants. Publications Office of the European Union, Luxembourg

Brown N, Venkatasamy S, Khittoo G, Bahorun T, Jawahee S (2009) Evaluation of genetic diversity between 27 banana cultivars (Musa spp.) in Mauritius using RAPD markers. Afri J Biotechnol 8 (9): 1834-1840

Buhariwalla HK, Jarret RL, Jayashree B, Crouch JH, Ortiz R (2005) Isolation and characterization of microsatellite markers from Musa balbisiana. Mol Ecol Notes 5:327-330

Changadeya W, Kaunda E, Ambali AJD (2012) Molecular characterisation of Musa L. cultivars cultivated in Malawi using microsatellite markers. Afri J Biotechnol 11(18): 4140-4157

Chen XM, Line RF, Leung H (1998) Genome scanning for resistance-gene analogs in rice, barley and wheat by high-resolution electrophoresis. Theor Appl Genet 97:345-355

Christelova P, Valarik M, Hribova E, Van den houwe I, Channeliere S, Roux N, Dolezel J (2011) A platform for efficient genotyping in Musa using microsatellite markers. AoB PLANTS plr024 https://doi.org/10.1093/aobpla/plr024

Collard BCY, Mackill DJ (2009) Start codon targeted (SCoT) polymorphism: a simple, novel DNA marker technique for generating gene targeted markers in plants. Pl Mol Bio Report 27:86-93

Crouch JH, Crouch HK, Tenkouano A, Ortiz R (1999) VNTR-based diversity analyses of $2 \mathrm{x}$ and $4 \mathrm{x}$ full-sib Musa hybrids. EJB Electr J Biotechnol 15:99-108

de Jesus ON, eSilva SD, Amorim EP, Ferreira CF, de Campos JMS, Silva GD, Figueira A, (2013) Genetic diversity and population structure of Musa accessions in ex situ conservation. BMC Plant Biol 13:41

Dempewolf H, Eastwood RJ, Guarino L, Khoury CK, Müller JV, Toll J (2014) Adapting agriculture to climate change: a global initiative to collect conserve, and use crop wild relatives. Agroecol Sustain Food Syst 38:369-377

D'Hont A, Denoeud F, Aury JM, Baurens FC, Carreel F, Garsmeur $\mathrm{O}$ et al (2012) The banana (Musa acuminata) genome and the evolution of monocotyledonous plants. Nature 488:213-217. https://doi.org/10.1038/nature11241

Elshire RJ, Glaubitz JC, Sun Q, Poland JA, Kawamoto K, Buckler ES, Mitchell SE (2011) A robust, simple genotyping-by-sequencing (GBS) approach for high diversity species. PLoS ONE 6:e19379

FAO (2009) Agricultural production status. Food and Agricultural Organisation, 2009; http:https://www.fao.org/faostat

FAO (2011) The World Banana Forum (WBF): Working together for sustainable banana production and trade. Introductory note. Accessed 23/2/2011. 2011; https://www.fao.org/economic/worldbananaforum

FAOStat. (2014) FAO production statistics for banana and plantain 2012. 2014; http://faostat.fao.org/site/567/DesktopDefault.aspx? PageID1/4567\#ancor (accessed on 20 Mar 14).

Food and Agriculture Organization of the United Nations (FAO) (2015) International Fund for Agricultural Development (IFAD) and World Food Program (WFP). (2015). The State of Food Insecurity in the World 2015. Meeting the 2015 International Hunger targets: Taking Stock of Uneven Progress. Rome, FAO. (Accessed June 2015) https://www.fao.org/3/a-i4646e.pdf

Freeland J, Kirk H, Petersen S (2011) Molecular ecology, 2nd edn. John Wiley and Sons, Chichester, UK, p 165

Gawel NJ, Jarret RL, Whittemore AP (1992) Restriction fragment length polymorphism (RFLP)-based phylogenetic analysis of Musa. Theor Appl Genet 84(3-4):286-290

Ge S, Hong D, Wang H, Liu Z, Zhang C (1998) Population genetic structure and conservation of an endangered conifer, Cathaya argyrophylla (Pinaceae). Int J Plant Sci 159:351-357

Ghalmi N, Malice M, Jacquemin JM, Ounane SM, Mekliche L, Baudoin JP (2010) Morphological and molecular diversity within Algerian 
cowpea (Vigna unguiculata (L.) Walp.) landraces. Gen Res Crop Evol 57:371-386

Godwin ID, Aitken EAB, Smith LW (1997) Applications of inter-simple sequence repeat (ISSR) markers to plant genetics. Electrophoresis 18:1524-1528

Golicz AA, Bayer PE, Barker GC, Edger PP, Kim H, Martinez PA, Chan CKK, Severn-Ellis A, McCombie WR, Parkin IAP et al (2016) The pangenome of an agronomically important crop plant Brassica oleracea. Nat Commun 7:13390

Gutterson N, Reuber TL (2004) Regulation of disease resistance pathways by AP2/ERF transcription factors. Curr Opin Plant Biol 7(4):465-471

Hajibarat Z, Saidi A, Hajibarat Z, Talebi R (2015) Characterization of genetic diversity in chickpea using SSR markers, Start codon targeted polymorphism (SCoT) and conserved DNA-derived polymorphism (CDDP). Physiol Mol Biol Plants 21(3):365-373

Hamidi H, Talebi R, Keshavarz F (2014) Comparative efficiency of functional gene-based markers start codon targeted polymorphism (SCoT) and conserved DNA-derived Polymorphism (CDDP) with ISSR markers for diagnostic fingerprinting in wheat (Triticum aestivum L.). Cereal Res Commun 44(4):558-567

Hamilton M (2009) Population genetics. Wiley-Blackwell, New York, NY, USA, p 234

Hippolyte I, Jenny C, Gardes L, Bakry F, Rivallan R, Pomies V, Cubry P, Tomekpe K, Risterucci AM, Roux N, Rouard M, Arnaud E, Kolesnikova-Allen M, Perrier X (2012) Foundation characteristics of edible Musa triploids revealed from allelic distribution of SSR markers. Annals Bot 109:937-951

IBA (2007) International Banana Association Banana facts: nutrition. Accessed 2007; 18/04/2007. https://www.eatmorebananas.com/ facts/nutrition.html

Igwe DO, Afiukwa CA, Ubi BE, Ogbu KI, Ojuederie OB, Ude GN (2017) Assessment of genetic diversity in Vigna unguiculata L. (Walp) accessions using inter-simple sequence repeat (ISSR) and start codon targeted (SCoT) polymorphic markers. BMC Genet 18:98

Igwe DO, Ihearahu OC, Osano AA, Acquaah G, Ude GN (2021) Genetic diversity and population assessment of Musa L. (Musaceae) employing CDDP markers. Plant Mol Biol Rep

Ilves A, Lanno K, Sammul M, Tali K (2013) Genetic variability, population size and reproduction potential in Ligularia sibirica (L.) populations in Estonia. Conserv Gen 14:661-669

INIBAP (2003) International Network for the Improvement of Banana and Plantain of Banana-Food and wealth, https://www.inibap. org. Jbir R, Hasnaoui N, Mars M, Marrakchi M, Triff M (2008). Characterisation of Tunisian pomegranate (Punica granatum L.) cultivars using amplified fragment length polymorphism analysis. Scientia Hort 115: 231-237

Jiang C, Gu X, Peterson T (2004) Identification of conserved gene structures and carboxy-terminal motifs in the Myb gene family of Arabidopsis and Oryza sativa L. ssp. indica. Genome Biol 5: R46. https://doi.org/10.1186/gb-2004-5-7-r46

Jiang L, Zang D (2018) Analysis of genetic relationships in Rosa rugosa using conserved DNA-derived polymorphism markers. Biotechnol Biotechnol Equip 32:88-94. https://doi.org/10.1080/ 13102818.2017.1407255

Jin FY, Shu HJ, Liu J (2016) Advances in population biology of Rosa rugosa. Acta Ecol Sin 36(11):3156-3166

Kaemmer D (1992) Oligonucleotide and amplification fingerprinting of wild species and cultivars of banana (Musa spp.) Bio/Technol 10 (9): 1030-1035

Karamura E, Frison E, Karamura DA, Sharrock S (1998) Banana production systems in eastern and southern Africa: bananas and food security-ed by C. Picq, E. Foure and Frison, INIBAP, Montpellier 401-412

Kastner T, Rivas MJI, Koch W, Nonhebel S (2012) Global changes in diets and the consequences for land requirements for food. Proc Natl Acad Sci USA 109(18):6868-6872
Kelager A, Pedersen JS, Bruun HH (2013) Multiple introductions and no loss of genetic diversity: invasion history of Japanese Rose, Rosa rugosa. Europe Biol Invasions 15(5):1125-1141

Khoury CK, Bjorkman AD, Dempewolf H, Ramirez-Villegas J, Guarino L, Jarvis A, Rieseber LH, Struik PC (2014) Increasing homogeneity in global food supplies and the implications for food security. PNAS 111:4001-4006

Kimura M, Ohta T (1973) Mutation and evolution at the molecular level. Genet 73(Suppl. 73):19-35

Lamare A, Rao SR (2015) Efficacy of RAPD, ISSR and DAMD markers in assessment of genetic variability and population structure of wild Musa acuminata colla. Physiol Mol Biol Plants 21(3):349-358

Lewontin RC (1972) Testing the theory of natural selection. Nature 236:181-182

Li LF, Hakkinen M, Yuan YM, Hao G, Ge XJ (2010) Molecular phylogeny and systematics of the banana family (Musaceae) inferred from multiple nuclear and chloroplast DNA fragments, with a special reference to the genus Musa. Mol Phylogenet Evol 57:1-10

Li T, Guo JE, Zheng CS (2014) Genetic diversity and construction of fingerprinting of chrysanthemum cultivars by CDDP markers. J Beijing For Univ 36(4):95-101

Li X, Bai T, Li Y, Ruan X, Li H (2013) Proteomic analysis of Fusarium oxysporum $\mathrm{f}$. sp. cubense tropical race 4-inoculated response to Fusarium wilts in the banana root cells. Proteome Sci 11: 41 http:// www.proteomesci.com/content/11/1/41 (accesed 20 October 2014).

Liu AZ, Kress WJ, Li DZ (2010) Phylogenetic analyses of the banana family (Musaceae) based on nuclear ribosomal (ITS) and chloroplast (trnL-F) evidence. Taxon 59:20-28

Liu K, Muse SV (2005) PowerMarker: an integrated analysis environment for genetic marker analysis. Bioinformatics 21(9):2128-2129

Mam A, Sakr MM, Adawy SS (2017) Assessing date palm genetic diversity using different Molecular Markers. Methods Mol Biol 1638:125-142

Martínez LE, Cavagnaro PF, Masuelli RW, Zuňiga M (2006) SSR based assessment of genetic diversity in South American Vitis vinifera varieties. Plant Sci 170:1036-1044

Millar C, Libby W (1991) Strategies for conserving clinal, ecotypic, and disjunct population diversity in widespread species. In: Falk DA, Holsinger KE (eds) Genetics and conservation of rare plants. Oxford University Press, New York, pp 149-170

Molina AB, Kudagamage C (2002) Report of the South Asia Network on Plant Genetic Resources (SANPGR) meeting held on December 9-11 at Plant Genetic Resources Center (PGRC), Peradeniya, Sri Lanka, 2002/12/09-11 INIBAP-BAPNET, Los Baños (PHL), p. 7.

Montenegro JD, Golicz AA, Bayer PE, Hurgobin B, Lee H, Chan CKK, Visendi P, Lai K, Doležel J, Batley J et al (2017) The pangenome of hexaploid bread wheat. Plant J 90:1007-1013

Nagasaki H, Sakamoto T, Sato Y, Matsuoka M (2001) Functional analysis of the conserved domains of a rice KNOX homeodomain protein, OSH15. Plant Cell 13:2085-2098

Nei M (1973) Analysis of gene diversity in subdivided populations. Proceedings of the National Academy of Sciences, USA 70:3321-3323

Nei M (1978) Estimation of average heterozygosity and genetic distance from a small number of individuals. Genet 89:583-590

Ning SP, Xu LB, Lu Y, Huang BZ, Ge XJ (2007) Genome composition and genetic diversity of Musa germplasm from China revealed by PCR-RFLP and SSR markers. Scientia Horti 114:281-288

Ntui VO, Tripathi JN, Tripathi L (2020) Robust CRISPR/Cas9 mediated genome editing tool for banana and plantain (Musa spp.). Current Plant Biol 21100128

Nyine M, Uwimana B, Swennen R, Batte M, Brown A, Christelova' P, Hřibova E, Lorenzen J, Dolezel J, (2017) Trait variation and genetic diversity in a banana genomic selection training population. PLoS ONE 12(6): 0178734

Opara UL, Jacobson D, Al-Saady NA (2010) Analysis of genetic diversity in banana cultivars (Musa cvs.) from the South of Oman using AFLP markers and classification by phylogenetic, hierarchical clustering 
and principal component analyses. Journal of Zhejiang UniversitySCIENCE B (Biomedicine \& Biotechnology) 11(5):332-341

Patil DM, Sawardekar SV, Gokhale NB, Bhave SG, Sawant SS et al (2013) Genetic diversity analysis in cowpea [Vigna unguiculata (L.) Walp.] by using RAPD markers. Int J Innov Biotechnol Biochem 1:15-23

Perrier X, Jacquemoud-Collet JP (2006) DARwin Software. http:// darwin.cirad.fr/darwin

Poczai P, Varga I, Bell NE (2011) Genetic diversity assessment of bittersweet (Solanum dulcamara, Solanaceae) germplasm using conserved DNA-derived polymorphism and intron- targeting markers. Ann Appl Biol 159:141-153

Poczai P, Varga I, Laos M, Cseh A, Bell N, Valkonen JPT, Hyvönen J (2013) Advances in plant gene-targeted and functional markers: a review. Plant Methods 9:6

Poerba YS, Ahmad F (2010) Genetic variability among 18 cultivars of cooking bananas and plantains by RAPD and ISSR markers. Biodiversitas 11(3):118-123

Pollefeys P, Sharrock S, Arnaud E (2004) Preliminary analysis of the literature on the distribution of wild Musa species using MGIS and DIVA-GIS. Montpellier, France: INIBAP. 2004; http://www.musal it.org/seeMore.php?id1/48616 (accessed on 18 Jan 2014), 68pp

Qu SQ (2013) [Evaluation and investigation of the germplasm of the precious species Cotoneaster schantungens is Klotz and Rosa rugosa Thunb] [master's thesis]. Tai' an: Shandong Agricultural University, Chinese

Rajamanickam C, Rajmohan K (2012) Diversity studies in ecotypes of banana (Musa spp.) using molecular markers and $\mathrm{D}^{2}$ analysis. J Hortl Sci 7(1):34-40

Rohlf FJ (2000) NTSYS-pc: Numerical Taxonomy and Multivariate Analysis System, version 2.2. Exeter Software. Setauket, New York

Ruas M, Guignon V, Sempere G, Sardos J, Hueber Y, Duvergey H, et al (2017) Musa Germplasm Information System (MGIS): managing banana (Musa spp.) genetic resources information and highthroughput genotyping data. Database (Oxford) 2017. https://doi. org/10.1093/database/bax046

Sami SA, Atia MAM (2014) A multidisciplinary molecular marker approaches to assess the genetic diversity in Egyptian date palm. Inter J Bio-Technol Res (IJBTR) 4(6):1-12

Sánchez Timm E, Hidalgo Pardo L, Pacheco Coello R, Chávez Navarrete T, Navarrete Villegas O, Santos Ordóñez E (2016) Identification of differentially expressed genes in response to Mycosphaerella fijiensis in the resistant Musa accession 'Calcutta-4' using suppression subtractive hybridization. PLoS ONE 11(8):e0160083

Seyedimoradi H, Talebi R, Fayaz F (2016) Geographical diversity pattern in Iranian landrace durum wheat (Triticum turgidum) accessions using start codon targeted polymorphism and conserved DNA-derived polymorphism markers. Environ Exp Biol 14:63-68

Silva AVC, Nascimento ALS, Vitória MF, Rabbani ARC, Soares ANR, Lédo AS (2016) Diversity and genetic stability in banana genotypes in a breeding program using inter simple sequence repeats (ISSR) markers. Genet Mol Res 16 (1): gmr16019402.

Skroch PW, Nienhuis J (1995) Qualitative and quantitative characterization of RAPD variation among snap bean (Phaseolus vulgaris) genotypes. Theor Appl Genet 91:1078-1085

Ssali RT, Nawankunda K, Erima RB, Batte M, Tushemereirwe WK (2010) On-farm participatory evaluation of East African Highland banana 'Matooke' Hybrids (Musa spp.). Acta Hortic 879:585-591

Stracke R, Werber M, Weisshaar B (2001) The R2R3-MYB gene family in Arabidopsis thaliana. Curr Opin Plant Biol 4:447-456. https://doi.org/10.1016/S1369-5266(00)00199-0

Talebi R, Nosrati S, Etminan A, Naji AM (2018) Genetic diversity and population structure analysis of landrace and improved safflower (Cartamus tinctorious L.) germplasm using arbitrary functional gene-based molecular markers. Biotechnol Biotechnol Equip. https://doi.org/10.1080/13102818.2018.1499443

Tester M, Langridge P (2010) Breeding technologies to increase crop production in a changing world. Sci 327:818-822

Toledo TT, Nogueira SB, Cordenunsi BR, Gozzo FC, Pilau EJ, Lajolo FM, do Nascimento JRO, (2012) Proteomic analysis of banana fruit reveals proteins that are differentially accumulated during ripening. Postharvest Biol Technol 70:51-58

Toral IMT, Caru M, Herrera MA, Gonzalez L, Martin LM, Miranda J, Navarro-Cerrillo RM (2009) Clones identification of Sequoia sempervirens (D. Don) Endl. in Chile by using PCR-RAPDs technique. J. Zhejiang Univ.-Sci B 10(2):112-119. [https://doi.org/10. 1631/jzus. B0820162].

Tripathi JN, Ntui VO, Ron M, Muiruri SK, Britt A, Tripathi L (2019) CRISPR/Cas9 editing of endogenous banana streak virus in the B genome of Musa spp. overcomes a major challenge in banana breeding. Communications Biol 2:46

Ude G, Pillay M, Nwakanma D, Tenkouano A (2002a) Analysis of genetic diversity and sectional relationships in Musa using AFLP markers. Theor Appl Genet 104:1239-1245

Ude G, Pillay M, Nwakanma D. Tenkouano A (2002b) Genetic diversity in Musa acuminata Colla and M. balbisiana Colla and some of their natural hybrids using AFLP markers. Theor Appl Genet 104 (8): 1246-1252

Ude G, Pillay M, Ogundwin E, Tenkouano A (2003) Genetic diversity in an African plantain core collection using AFLP and RAPD markers. Theor Appl Genet 107:248-255

Van ZM, Scheldeman X, Escribano P, Viruel MA, van Damme P, Garcia $\mathrm{W}$ (2012) Mapping genetic diversity of cherimoya (Annona cherimola Mill.) and application of spatial analysis of conservation and use of plant genetic. PLoS One 7(1): e29845

Vinceti B, Loo J, Gaisberger H, Van Zonneveld MJ, Schueler S, Konrad $\mathrm{H}$ (2013) Conservation priorities for Prunus africana defined with the aid of spatial analysis of genetic data and climatic variables. PLoS ONE 8(3): 59987

Wang XL, Chiang TY, Roux N, Hao G, Ge XJ (2007) Genetic diversity of wild banana (Musa balbisiana Colla) in China as revealed by AFLP markers. Genet Resour Crop Evol 54:1125-1132

Wang Y, Xia Q, Wang G, Zhang H, Lu X, Sun J, Zhang X (2017) Differential gene expression in banana roots in response to Fusarium wilt. Can J Plant Pathol 39(2):163-175

Xie Z, Zhang ZL, Zou X, Huang J, Ruas P, Thompson D, Shen QJ (2005) Annotations and functional analyses of the rice WRKY gene superfamily reveal positive and negative regulators of abscisic acid signaling in aleurone cells. Plant Physiol 137:176-189. https://doi.org/10. 1104/pp.104.054312

Yang JH (2009) [The study on genetic diversity of the endangered species Rosa rugosa in China and factors influencing genetic diversity] [master's thesis]. Tai' an: Shandong Agricultural University, Chinese

Yang QS, Gao J, He WD, Dou TX, Ding LJ, Wu JH, Li CY, Peng XX, Zhang S, Yi GJ (2015) Comparative transcriptomics analysis reveals difference of key gene expression between banana and plantain in response to cold stress. Genomics 16:446

Yeh FC, Boyle TJB (1997) Population genetic analysis of co-dominant and dominant markers and quantitative traits. Belg J Bot 129:157

Youssef M, James A, Rivera-Madrid R, Ortiz R, Escobedo-Gracia Medrano RM (2011) Musa genetic diversity revealed by SRAP and AFLP. Mol Biotech 47(3):189-199

Publisher's Note Springer Nature remains neutral with regard to jurisdictional claims in published maps and institutional affiliations. 